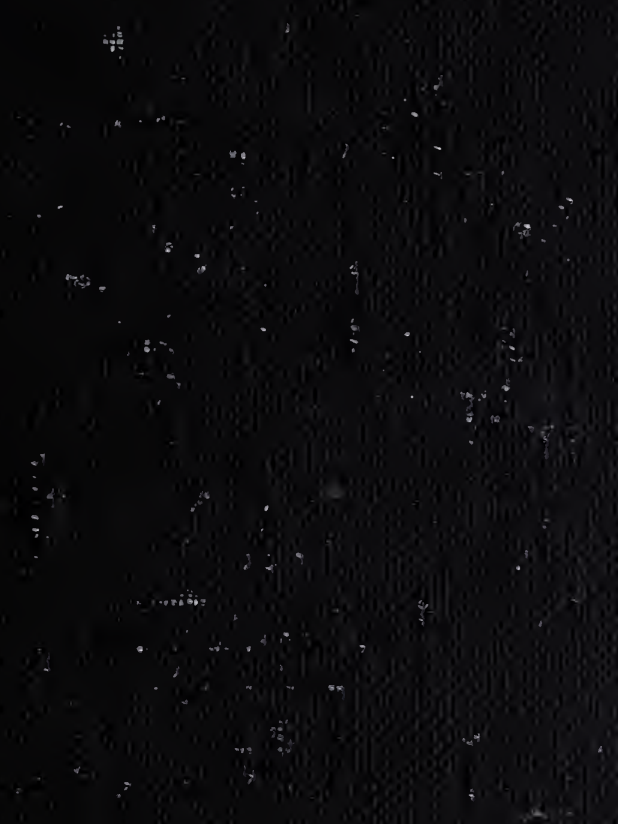

y.s.

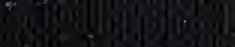
Cis

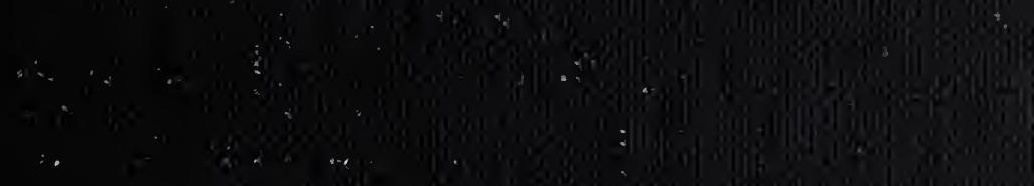


Natural History Museum Library

000147753

OP

Aa

o

$B R I$ 

13.28

s.

18 


\section{S Y N O P S I S}

OF

$\mathbb{T} \mathbb{H} \mathbb{E} C O N \mathbb{T} \mathbb{E} \mathbb{T} S$

OF THE

K

\section{BRITISH MUSEUM.}

FOURTEENTH EDITION.

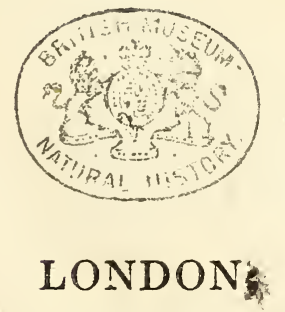

PRPNED BY RICHARD AND ARTAUR 'TAYLOR, SHOE-LANE.

1818. 


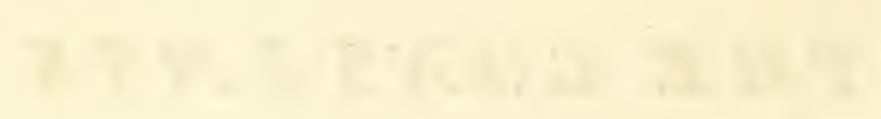




\section{CONTENTS.}

PART I.

Rooms

Lower Rooms.

Page

I.-XVI. Library of printed Books............ I

Upper Floor.

I. Miscellaneous Articles ............ 2

II. Ditto...................... 7

III. Lansdown Manuscripts $\ldots \ldots \ldots \ldots \ldots \ldots \ldots$

IV. Sloane and Birch Manuscripts ......... 8

V. Harleian Manuscripts .............. 9

VI. Harleian MSS. and Additions ......... 9

VII. Royal and Cottonian MSS. .......... 12

The Saloon, Minerals .............. 13

VIII. Zoology .................. 56

IX. Petrifactions or Fossil Remains of Animals and Vegetables.................61 61

X. British Oryctognostic Collection ........ 62

XI. In course of arrangement.

PART II.

Gallery.

I. Terracottas .................... 1

II. Greek and Roman Sculptures ......... 10

III. Ditto ..................... 12

IV. Ditto ....................... 16

V. Roman Sepulchral Antiquities ......... 71

VI. Greek and Roman Sculptures ......... 21

VII. Roman Antiquities $\ldots \ldots \ldots \ldots \ldots \ldots \ldots . . .61$

VIII. Egyptian Antiquities ............. 32

IX. Ditto ...................... 34

X. Greek and Roman Sculptures .......... 39

XI. Coins and Medals ............... 47

XII. Sir Willian Hamilton's Collection ....... 50

XIII. Prints and Irawings $\ldots \ldots \ldots \ldots \ldots \ldots \ldots$. $5 . \ldots \ldots$

XIV. Phigalian Marbles, \&c. ............. 56

$\mathrm{XV}$. Lord Elgin's Collection .............. 60

Portland Vase, \&c. Ante-Room.

$$
\text { Ante-Room. }
$$


The pullic are apprised that this Synopsis is merely intended for the use of Persons who take a cursory view of the Museum. The following is a list of the more ample descriptions of several parts of the Collection. Those marked with an asterisk are progressive.

Descriptions of the Ancient Terracottas, by T. Combe, 1810,4 to.

* - Marbles, parts 1,2 and 3, by the same, 1812, 4to.

* A Catalogue of the Greek Coins, by the same, 1814, 4to.

* - Library of Printed Books A-S. by H. Ellis and H. H. Baber, 1813, \&c. 6 vol. 8 vo.

Cottonian MSS. by J. Planta,1802, fol. Harleian MSS. by H. Wanley and R. Nares, 1808, 3 vol. fol. MSS. of the King's Library, by Casley, 1734, 4to.

MSS. heretofore undescribed, by S. Ayscough, 1782, 2 vol. 4to.

* A part of the Catalogue of the Lansdown MSS. is printed, but not yet published.

A brief introductory Statement of the original Foundation and progressive Increase of the Establishment, may be had from the Messenger at the Museum. 


\section{S Y N O P S I S}

OF THE

CONTENTS OF THE BRITISH MUSEUM.

PaIt I.

Ov entering the gate of the Museum, a spacious quadrangle presents itself, with an Ionic colonnade on the south side, and the main building* on the north; the two wings being allotted for the dwellings of the Officers. The Architect, Peter Puget, a native of Marseilles, and an artist of the first eminence in his time, was sent over from Páris by Ralph, first Duke of Montagu, for the sole purpose of constructing this splendid Mansion.

\section{GROUND FLOOR.}

\section{LIBRARY OF BOOKS.}

The first floor, consisting of sixteen rooms, con- Librazy of tains the Library of Printed Books: Strangers are

* The building measures 216 feet in length, and 57 in height, to the top of the cornice. 
not admitted into these apartments, as the mere sight of the outside of books cannot convey either instruction or amusement*.

The decorations of the great staircase have been lately restored. The paintings on the ceiling, representing Phaëton petitioning Apollo for leave to drive his chariot, are by Charles de la Fosse, who, in his time, was deemed one of the best colourists of the French school; and of whom there are many valuable performances in France, among which are the paintings on the cupola of the dome of the Invalids, which are ranked among the admiranda of Paris. The landscapes and architectural decorations are by James Rousseau, whose particular skill in perspective has at all times been held in high estimation.

\section{UPPER FLOOR.}

\section{FIRST ROOM.}

Room I. This room, in its present state of arrangement, contains miscellaneous collections.

On the tables are deposited objects relative to

* An Alphabetical Catalogue of this Library was printed in the year 1787, in two volumes folio; but as great accessions have been obtained of late, this Catalogue is now under revision, and a new edition, greatly enlarged, is in the press.

technical 
technical mineralogy, or mineral substances in a RоOм 1 . rough state, with the scientific and familiar names affixed to them.

Lavas and other volcanic productions, in largepolished pieces, principally from Mount Vesuvius; and miscellaneous specimens of minerals of considerable dimensions, with their names and localities affixed.

The remaining cases contain articles from the west coast of North America and the South Sea Islands.

(Shelves 1-3.) Fishing implements from Noot- CASE 11 . ka Sound and Oonalashka: harpoons: lines made of sinews, and of sea-weed (a species of Fucus), \&c. -Models of fishing-boats, \&c.: water-proof fish-. ing-jackets, made of the intestines of the whale, from Nootka Sound.-Several caps of wood, representing heads, of beasts; a bird's head of wood, ornamented with feathers, \&c.: a wooden coat of armour : birds made of wood, hollow, and contain. ing stones, used as rattles; from Nootka and Oonalashka.

(Shelvês 1-5.) Warlike implements and vari- CAsE 12. ous tools, clubs, adzes, \&c.: Patoo-patoos of wood and bone, \&c. Various domestic utensils from the same part of the coast. A screen made of the feathers of an eagle: knives : spoons : eating-bowls : bread made of the root of the Cassada tree (a species of Jatropha), with an unprepared piece of the latter.-Caps of various shapes and colours; some 
Rоом I. with representations of the whale fishery: combs, \&c. from Nootka and Oonalashka.

CASE 13. (Shelves 1-3.) Baskets made in various parts of the west coast of North America.-Mattings, \&c. The inner bark of a species of cypress (Cupressus thuyoides) in its different stages of preparation, for making mats, garments, \&c.-Specimens of sculpture: imitations of the human form: masks, \&c.

CASE 14. Various kinds of fur: garments made of leather, from the west coast and other parts of North America : an Indian coat made at Manchester House, lat. 52. 30. long. 107. A coat made of the feathers of the cormorant.

ASES Otaheite winter and summer cloths made of the 15 and 16. bark of the paper mulberry (Broussonetia), and variously dyed.-A mourning dress : a breastplate made of feathers, \&c., used in war: \&c.

CaSE 17. (Shelves 1-3.) Coarse mats for sails, \&c. Basket-work and cordage.-Ornamental mats made of a kind of flag: a dancing-apron, \&c. from Otaheite.

CASE 18. (Shelves 1-5.) Fishing implements.-Various utensils made of a basaltic stone: rasps made of shagreen: wooden pillows : adzes of a kind of jade, called axe-stone: \&c.-Ornamental carvings: cloth beater : plaited hair: tatooing instruments: a planting spade made of a fragment of a shield: nose flutes: abread fruit.-Various stone adzes, hatchets, \&c. 
Large cloaks : aprons : helmets : hats : distorted ROOM I, human figures, \&c. made of feathers.-From the Sandwich Islands.

(Shelves 1-3.) Various specimens of mats and cloths : gorgets made of red seeds, \&c.-Cordage: slings: cloth beaters: hair for ornamental headdresses.-Fishing-hooks made of bones and shells; saws made of sharks' teeth; and other tools.-From the Sandwich Islands.

(Shelves 1, 2.) Articles of ornament: bracelets CASE 22. made of boars' tuslss, and of tortoise-shell : assortment of shells and seeds, \&c.-Necklaces, and other ornaments. Coverings for the legs, composed of shells, seeds, and teeth, used in dancing: round mirrors made of a black slaty stone, which is wetted for use : quoits : weights, \&c.-From the Sandwich Islands.

(Shelves 3, 4.) Small cloaks : a head-dress, and other ornaments made of feathers: a specimen of the species of creeper (Certhia vestiaria) which supplies the red feathers.-Fans : wooden bowls supported by grotesque figures for ornament.-Mostly from the Marquesas.

(Shelves 1-3.) Specimens of cloth, matting, CASE 23. and cordage.-Basket-work, plain and ornamented: screens for the sun.-Ornamental basket-work: various pouches : a dancing-dress made of the fibres of the bark of cocoa-nuts. - From the Friendly Islands. 
ROOM 1. (Shelves 1-5.) Fishing implements, hooks, and

CASE 24. various nets: models of canoes: adzes made of shells : tatooing instruments: rasps, \&c.-Various articles of ornament: necklaces made of shells, seeds, \&c. : combs : bracelets: kernels of a nut which when burnt yields a strong light.-Aprons and other ornaments made of the thigh-bones of a small bird: nasal flutes: fly-flaps: a shuttle, \&c. - Various Cava bowls of wood curiously carved: some eartheri vessels, \&c.-From the Friendly Islands.

CASE 25. (Shelves $1-3$.$) Various specimens of matting$ and cordage, mostly made of the New Zealand hemp (Phormium tenax).-Sundry woven articles : belts, \&c.-Fishing-nets : hooks : cordage, \&c.From New Zealand.

CASE 26. (Shelves 1-3.) Articles of ornament: combs: necklaces, \&c. Specimens of carving in wood and bone: pipes, and other musical wind instruments. -Warlike instruments: conchs used in war: clubs: saws made of sharks' teeth for dissecting the bodies of their enemies : two human hands, being parts of the body of a slain enemy. Tools of various kinds, \&c. - Various wooden boxes ornamented with carvings.-Boat scoops, \&c.-From New Zealand.

Over the Cases 11-14. Various missile weapons from different parts of the west coast of North America and the islands of the South Sea: har-

poons, 
poons, jarelins, spears : a wooden shield : also va- Rоoм I. rious calabashes, some inclosed in wicker-work.

Over the Cases 18-20. Bows, arrows, quivers, drums, \&c.

Round the Door opposite the Entrance. Various sorts of plain and carved clubs, maces, \&c.

Over Case 21. A large Cava bowl: wooden pillows.

Over Case 23. A canoe composed of many pieces of wood sewed together, from Queen Charlotte's Island: various kinds of paddles, \&c.

Over the Cases 25 and 26. A large wooden drum with lateral opening, made of the trunk of a tree: a wooden box, \&c.

\section{SECOND ROOM.}

This room is at present empty.

ROOM II.

\section{THIRD ROOM.}

\section{LANSDOWN LIBRARY OF MANUSCRIPTS.}

This library, which having been lately acquired room In is not yet finally arranged, consists of 1352 volumes, Lansdown of which 114 contain an ample collection of Lord MSS. Burleigh's State Papers, many of them originals : 46 volumes of Sir Julius Cæsar's papers, all relative to the history of the time of Queen Elizabeth and King James I. : 108 volumes of historical collections 
Room iri. tions of Dr. WhiteKennet, Bishop of Peterborough:

- a considerable number of original royal and noble letters and papers: and a great store of historical, juridical, biographical, heraldical, and miscellaneous collections*.

\section{FOURTH ROOM.}

\section{SLOANEAN AND BIRCH'S COLLECTIONS OF} MANUSCRIPTS.

RoOm IV. A collection of MSS. bequeathed by the late Three Presses between the Windows. Dr. Birch, consisting of 337 volumes, chiefly on history, biography, divinity, and literature.

Birch's MSS. Sir Hans Sloane's library of MSS. consisting of Presses III.XXX. 4100 volumes, principally on physic, natural hisSloanean MSS. tory, and natural philosophy. It also contains Kæmpfer's MSS.; several journals of voyages ; and some Oriental MSS.

In a recess, within this room, are placed Mr.Halhed's and some other collections of Oriental MSS. A collection of MSS. and Rolls, consisting of 62 articles relating to Kent, purchased of Mr. Hasted: and some select MSS. out of the other libraries in the Museum.

* The repertory to this library being at present nothing more than a sale catalogue, and of course very imperfect, will require to be newly constructed on the enlarged plan of the other catalogues belonging to this Institution. Considerable progress has been made in this work; but it must be some time before it can be completed.

Orer 
Over the chimney is a drawing of the palace of room IV. Colomna, near Moscow, which belonged to the Czars of Moscovy; it was built of wood, and is now demolished.-Presented by the Honourable Percy Wyndham*.

\section{FIFTH ROOM.}

\section{HARLEIAN LIBRARY OF MANUSCRIPTS.}

The greatest part of the Harleian Library of room v. Manuscripts is deposited in this Room, which is at present appropriated for the use of the readers.

\section{SIXTH ROOM.}

The remainder of the Harleian Library of Manu- Room vi. scripts is deposited in this Room $\uparrow$.

Also Many adDitions by GIFT, BEQUest, AND PURCHASE; among which are particularly remarkable Fifty-seven volumes, containing a series of Public Acts relating to the history and government of En-

* A catalogue of the contents of this Room, and of most of the additional acquisitions in the fifth Roorn, compiled by the Rev. S. Ayscough, was printed in the year 1772 , in two volumes quarto.

+ A catalogue of these MSS. was printed in the year 1759, in two volumes folio; but the latter part of it was found so defective, that it became necessary to have it corrected and enlarged. This improved work is now completed, and, with copious Indexes, furms four volumes. folio.

gland, 
ROom vi. gland, from the year 1115 to 1608 , collected by MSS. Thomas Rymer; but not printed in his Fœdera; and sixty-four volumes of Rolls of Parliament; the whole ordered to be deposited in the Museum, by the House of Lords.

A collection in forty-seven volumes, relating to the History of Ireland: presented by the Rev. Jeremiah Milles, Dean of Exeter.

Forty-three volumes of Icelandic Manuscripts; presented, with a much more numerous collection of printed books, by the Right Hon. Sir Joseph Banks, Bart. K.B.

Forty-one volumes, containing the decisions of the Commissioners for settling the City estates after the fire of London: presented by Thomas Cowper, Esq.

Twenty-four volumes relating to the history of Music, which, together with a considerable collection of printed books on the same subject, were bequeathed by Sir John Hawkins.

Twenty-seven volumes of music, chiefly mottets, and other church music, by old composers, (Prenestini, Palestrina, Pergolese, Steffani, Handel, \&c.) bequeathed by James Mathias, Esq.

Thirty-eight volumes of manuscripts, and nine of drawings, being a copious collection towards a topography and history of the county of Sussex; bequeathed by Sir William Burrell.

Forty-four volumes, thirty-two of which contain 
an obituary kept by the donor, the rest being a col- Room VI. lection of autographs, original warrants, and other MSS. documents, catalogues of portraits, \&c. bequeathed, together with a considerable library of printed books, by Sir William Musgrave, Bart.

A numerous collection of manuscripts, chiefly relating to the county and university of Cambridge, bequeathed by the Rev. William Cole, M.A.

In the presses $\frac{I}{2}$ and XVI. are two rolls of the Pentateuch on vellum, the former of considerable antiquity, and the latter much more recent: this latter, together with a considerable number of $\mathrm{He}-$ brew MSS. and printed books, was presented by Solomon Da Costa, Esq.

Against the press $\frac{1}{2}$ hang three specimens of minute writing, forming the portraits of Queen Anne, Prince George of Denmark, and the Duke of Gloucester their son.

Against the press XVIII. hangs an original deed in Latin, written on papyrus, being a conveyance of some land to a monastery; dated Ravenna, $A^{\circ} 572$, bought at the sale of the Pinelli library. And opposite to it is a large specimen of the reed (Cyperus Papyrus) of which that kind of paper is made.

In the second window hangs an Italian note to Sir William Hamilton, written on modern papyrus, explaining the mode of preparing it. 


\section{SEVENTH ROOM.}

THE ROYAL LIBRARY OF MANUSCRIPTS,

Deposited in XXXIII. Presses.

\section{THE COTTONIAN LIBRARY OF MANUSCRIPTS,}

Deposited in XXI. Presses.

RоOм vir. These two libraries are not classed in a strict sciMSS. entific order*.

In the press under No. XIX. of the Cottonian library are deposited ninety-four volumes of extracts, transcripts, and notes, chiefly relating to the Exchequer, collected by Thomas Maddox, Esq. historiographer to Queen Anne and King George I. and bequeathed by his widow; as an addition to the Cottonian library.

On the table, in a glazed frame, is the original of the Magna Charta, belonging to the Cottonian library; and on the side of it is a fac-simile engraving of it, by Pine.-Against press XXI. of the Cottonian library is the original of the Articles preparatory to the signing of the great Charter, perfect with the seal; presented Anno 1769 by Eari Stanhope.

* Of the King's Library, a catalogue compiled by Mr. David Casley was printed in the year 1734, in quarto: and of the Cottonian $\mathrm{Li}$ brary, there are no less than three catalogues extant: the first by Dr. Thomas Smith, printed 1696, folio; the second, being an attempt towards a classical arrangement, printed in 1777, octavo; and the third, improved and considerably enlarged by Mr. Planta, printed by His Majesty's command, in the year 1802, folio. 


\section{THE SALOON.}

The dome of this grand apartment painted by SALOON. the above-mentioned La Fosse represents the birth of Minerva. The landscapes and architectural decorations are by the same $\mathbf{J}$. Rousseau who painted in the staircase ; and the garlands of flowers are by John Baptist Monoyer, the most eminent flower painter of his time. Over the chimney is a full length portrait of King George II., by Shackleton.

This apartment contains the principal collection of Minerals of the Museum, systematically arranged, the more characteristic specimens being exhibited in the tables, and the remainder in the drawers underneath. In the arrangement of this collection a natural order founded on external characters has been followed; not, however, without consulting the chemical composition of the substances, so far as convenience would admit. Each of the glazed table-cases has its number inscribed on the upper part of the middle square of glass.

(Case 1.) contains the combustible substances, among which may be particularized the different varieties of bitumen, from the fluid naphtha, to the solid jet (pitch coal of Werner) and the mineral Caoutchouc from Derbyshire (See British collec- 
SALoon. collection: Derbyshire). With these is placed $\mathrm{NaT.}_{\text {Ast. }}$ an inflammable fossil substance found by Humboldt in South America, where it is called $d a$ peche, which has several of the properties of the common caoutchouc or India rubber; also the retinasphaltum found at Bovey, and that from Wildshut and Bergen in Bavaria; the peculiar resinous substance discovered in digging the tunnel at Highgate, \&c.-To the varieties of amber is added some wood converted into brown coal, and a small capsular fruit, both of which are found, together with that inflammable substance, on the coast of Prussia. - Sulphur, crystallized and massive, with selenite, sulphate of strontian, \&c.; the same found sublimed near the craters of volcanos. - Graphite, commonly called black lead, massive, disserninated in porcelain earth, \&c.-A few specimens of black coal.Browncoal, to which belongs the well known Bovey coal.-Dysodile, or papyraceous brown coal.Among the specimens of anthracite or kohlenblende (to which maybe referred the Kilkenny coal) is a specimen from Kongsberg in Norway, with native silver.

(Case 2.) The diamond, though combustible, is by common consent considered as the first of precious stones : among the specimens selected to exemplify its crystalline forms, are, the primitive regular octohedron; the same with solid angles truncated; with edges truncated, forming the passage 
into the regular dodecahedron; varieties of the latSALOON. ter, giving rise to the six-sided prismatic and the tetrahedral forms; cubes with truncated and beNat. His's. villed edges; various hemitropic crystals or macles of diamonds, \&c. With these are also placed specimens of the alluvial rocks in which the diamonds occur in the East Indies and in Brasil. - Pyrorthite and orthite, two newly discovered Swedish minerals, analysed by Berzelius, the former of which contains 30 per cent. of inflammable matter; both are allied to Gadolinite, of which a fine and scarce crystal is here deposited.-Tantalite from North America, Bavaria, and Sweden.-Zircon: to which belong the common jargon of various colours, and the orange-coloured, considered by some as the true hyacinth, from Auvergne, Chili, \&c. ; also the variety called zirconite, from Friedrichsvärn in Norway, imbedded in syenite, a rock composed of feldspar and hornblende.-Corundum : which comprehends the precious stones commonly called oriental gems (the sapphire, ruby, oriental amethyst, oriental topaz, oriental emerald), of the crystalline forms of which the principal modifications are here exhibited; and the common or imperfect corundum from Bengal, Mysore, China (the diamant spath of Werner), Lapland, Piedmont, \&c.-As appendix to these are added the fibrolite (bournonite of $\mathrm{Lu}$ cas), one of the concomitant substances of com- 
SALOON. mon corundum; and the emery which owes its Nат. НІгт. hardness and consequent usefulness in polishing to an adinixture of blue corundum.-Among the many varieties of spinel we have the ceylonite or pleonaste, by some still considered as a distinct species, and the blue spinel from Åker in Südermania. Another substance nearly related to this species, is the automolite from Fahlun in Sweden, being the spinelle zincifère of Haüy.-As chemically allied to the substances in this table-case are added the hydrates of alumine, comprehending the foliated (diaspore), and the radiated (hydrargillite or wavellite) varieties; to which may be referred, as compact variety, the turquois, from Chorazan in Persia, where it occurs in nodules like those here preserved. Between the common corundum of this and the feldspar of the contiguous opposite table-case, is placed the andalusite, which was first considered as a congener of the former, and afterwards referred to the latter (as feldspath apyre), but appears to be distinct from both.

(Case 3.) Among the specimens of chrysoberyl or cymophane may be noticed the North American variety, in its matrix of quartz and feldspar, with small trapezoidal garnets.-Kyanite or disthene, massive, in separate crystals and imbedded, with grenatite, \&c. : also in small polished pieces, which are sometimes mistaken for sapphires.-A series of crystals 
crystals of Brasilian, Sảxon, and Siberian topazes, among which there are some new modifications; SALOON. Saxon varieties, imbedded in the topaz rock, an aggregate of topaz, shorl, quartz, and sometimes mica. -Emerald and beryl : several crystals of the South American emerald, insulated and in their matrix; emeralds from Salzburg. Beryls of various colours, the most common of which is the variety called aqua-marine: the fine groups of these, found in ferruginous loam at Nerchinsk and Adontchelong in Siberia, are very remarkable; large crystals of emerald or beryl from Limoges in France, and from Rabenstein in Bavaria, the latter accompanied by tantalite:-Near the beryl (though perhaps not very nearly related to it) is placed the euclase, a rare crystallized mineral substance, discovered by Dombey, in Peru.-The pycnite, referred by Werner to the beryl, under the name of shorlous beryl, and considered as a variety of topaz by Haïy, is here placed between those two species.-Also the pyrophysalite from Fahlun in Sweden, considered by the same crystallographer as a variety of topaz. - This case also contains the tourmaline and common shorl. Among the varieties of the former may be specified the mbellite, also called siberite (tourmaline apyre of Haüy), a remarkable specimen of which, both with regard to form and volume, is here preserved: it was presented by the King of Ava to the late Colonel Symes, when on an embassy 
SALOON. to that country, and afterwards deposited by the latNat. Hist. ter in Mr. Greville's collection. Other red and blue varieties from Siberia, and from Massachusets in North America; the flesh-coloured tourmaline from Rozena in Moravia (which is by some considered as a variety of pycnite), \&c.-Varieties of common shorl.

(Case 4.) In this and the following case are arranged the substances belonging to the species of quartz.-Rock crystal: various modifications of its crystalline forms: small dodecahedral and other crystals, known by the trivial names of Gibraltar diamonds, Bristol diamonds, \&c.; varieties of colour according to which the crystals obtain the vulgar denominations of smoky topaz or morion, cairngorm, citrine, \&c. ; specimens of rock crystal, inclosing various substances, such as rutile, brown iron-stone, micaceous iron, needle antimony, actinote, asbest, chlorite, \&c.; groups of rock crystal. -Amethyst quartz of various tints, in grouped crystals; nodule lined with crystals of amethyst and cross stone or harmotome, from Oberstein. To this is added the thick-fibrous amethyst of Werner, considered by others as a sub-species of common quartz.

(Case 5.) Common quartz: among the specimens of this widely diffused substance, which offers such great variety in its external aspect, the more remarkable are those of hacked, corroded and cellular quartz 
from Schemnitz, as also the pseudomorphous or supSALOON: posititious crystals, principally derived from modifications of calcareous and fluor spars; and, with NAT. Hisr regard to colour, the red quartz crystals from Compostella, imbedded in gypsum, and known by the name of hyacinths of Compostella; the siderite from Salzburg; the blue quartz of Orrayervi in Finland, called steinheilite.-Among the varieties of quartz is the rose or milk quartz, which occurs only massive, the prase, which appears to be an intimate mixture of common quartz and actinote.-In this case are also deposited some varieties of the cat'seye (mostly from Ceylon): a substance generally referred to the natural order of quartz.

(Case 6.) Besides some specimens of substances related to common quartz, such as the avanturino quartz, the flexible sandstone from Brasil, and the iron-fint (a substance in which oxide of iron exists in chemical union with silica), this case contains varieties of the stalagmitical quartz, also called quartz sinter. The most remarkable among these are the siliceous concretions deposited by the celebrated hot spring in Iceland, the Geyser, and which are distinguished into siliceous tuf, and calcedonic sinter. Another variety of it is the pearl sinter from Santa Fiora in Tuscany (whence it obtained the name of Fiorite), and from the island of Ischia. 'To this may also be referred the ceraunian sinter, or those enigmatical siliceous tubes, which were first 
SaLOoN. found in the sands of the Senner heath, in the Nat. Hrst. county of Lippe (where, from their supposed origin, they are called lightning tubes), and subsequently, under similar circumstances, at Drigg, on the coast of Cumberland, which is the locality of the specimen here deposited. [See also British Coll.] -The hyalite is placed here, as a mineral related both to stalagmitical quartz and calcedony.-The rest of this table-case, and the greater part of the following, are occupied by calcedonic substances. Among the specimens of common calcedony, the most remarkable are the smalt-blue variety from Felsobanya in Transylvania, crystallized in cubes; the branched and stalactical calcedony from Iceland, \&c.; the botryoidal from Ferroe; nodules including water (enhydrites) from Monte Berico, near Vicenza, where they are said to occur in volcanic rocks; cut and polished pieces of calcedony, with black and red dendritic and other figures, vulgarly called mocha stones; varieties with white, brown, and black, straight or curved lines: onyx, sardonyx, \&c.

(Case 7.) Calcedonic substances continued. Among these are various specimens of the red and yellowish varieties of calcedony, called carnelian: striped carnelians, \&c.-Heliotrope, an intimate mixture of calcedony and green earth, which, when containing disseminated particles of red jasper, is commonly termed blood-stone.-The beautiful and much esteemed variety of calcedony, called chryso. 
prase: it has hitherto been only found at Kosemütz in Silesia, accompanied by a siliceous earthy substance called pimelite, which, like the chrysoprase, owes its green colour to oxide of nickel. - By way of appendix to the calcedonic substances, are added a few specimens of the less compound varieties of agates, in which common calcedony, carnelian, and heliotrope respectively form the predominant ingredients. - Of fint, a well known mineral substance, several interesting varieties are deposited in this case.

(Case8.) contains principally opaline substances, viz. specimens of the noule opal, which owes its beautiful play of colours to a multiplicity of imperceptible fissures in its interior; the Mexican sum or fire opal; the common opal, a translucent white variety of which, appearing yellow or red when held between the eye and the light, is called girasol; the semi-opal, agreeing in its principal characters with the common; specimens of those varieties which, having the property of becoming transparent when immersed in water, are called hydrophanes, and vulgarly oculus mundi; wood-opal, or opalized wood; iasp-opal, referred by some authors to jasper; the menilite, called also liver-opal, found at MenilMontant, near Paris, in a bed of adhesive slate, a specimen of which is added. Some varieties of cacholong may likewise be referred to the opal-tribe. - The remainder of this case is occupied by the si: 
SALOoN. liceous substance called hornstone, divided into the $\mathrm{NAT}_{\mathrm{A} . \mathrm{H}}$ Isto conchoidal and splintery varieties; among these are the remarkable pseudomorphous crystals from Schneeberg in Saxony, derived from various modifications of calcareous spar, and generally referred to conchoidal hornstone; also some beautiful specimens of wood converted into hornstone, being the wood-stone of Werner; hornstone balls, from Haunstadt in Bavaria.-Flinty-slate, \&c.

(Case 9.) In this case are deposited the different varieties or subspecies of jasper, such as they are enumerated by Werner, viz. the globular or Egyptian jasper, found chiefly near Cairo, in rounded pieces, which appear not to owe their form to rolling, but to be original and produced by infiltration; the ribbon jasper, or striped jasper, the finest varieties of which are found in Siberia; the variouslytinted common jasper; the agate jasper, found only in agate veins; the porcelain jasper, which is produced by the agency of subterraneous fire.-In this case are also contained the substances constituting the obsidian tribe, to which belong the pitch-stone, which is often confounded with semi-opal; - the pearl-stone, so called from its colour and the small globular concretions of which it is composed;-the obsidian, a remarkable variety of which is that found iu globular pieces, at Ochotsk in Siberia, near the small river Marekanka, from which it has obtained the name of Marekanite;-pumiee, which is not in 
all cases of volcanic origin. Near these substances are placed some specimens of the iolite of Werner, also called dichroite from its exhibiting two different SALOON. colours when viewed in different positions.

(Case 10.) This case contains zeolitic substances, viz. several varieties of scolicite and of mesotype, among the specimens of which may be particularized. those with perfect prismatic acicular crystals (needlestone of Werner); the delicately fibrous varieties; the red compact variety, by some called crocalite, \&c.-The natrolite of Klaproth, of which a few specimens are added, is by some considered as a variety of mesotype.-Stilbite, mostly crystallized: among the coloured varieties is the red from Fassa (Fassait).-Apophyllite, some varieties of which have been mistaken for mesotype and stilbite.Analcime, among the crystallized varieties of which are remarkably large specimens of the trapezoidal modification.-Chabasite or chabasie, in groups of primitive rhombohedral and modified crystals.

(Case 11.) Continuation of zeolitic substances: - Prehnite, crystallized and massive, the grassgreen variety of which, discovered in South Africa by the Abbe Rochon, has been mistaken for chrysolite, chrysoprase, and even emerald. To this belongs also the koupholite; and the substance known by the name of Chinese jade, of which some specimens are added, may likewise be referred to Prehnite. - Harmotome, or cross stone, both in simple and cruciform 
SALOON. cruciform crystals, from Oberstein, Strontian, and Nat. Hrst. Andreasberg in the Hartz, which last locality has procured to this substance the names of andreolite and hercinite.-Among those substances deposited in this case which are in some respects related to zeolitic minerals, may be observed the lazulite or lapis lazuli, which furnishes the valuable pigment known by the name of ultramarine; and the haiiyne, a mineral so called in honour of the celebrated French crystallographer. Intermediate between the zeolitic substances and feldspar, are placed some mineral species which cannot be referred to either of these tribes: among them are the meionite and sommite, both from Vesuvius; the scapolite, a Norwegian mineral, of which several varieties are known under different names, such as the vitreous scapolite, the compact and the common scapolite (called also wemerite, after the late illustrious professor of Freiberg); the talc-like scapolite (micarelle of some authors), \&c. Also the bergmannite, and the fettstein of Werner are related to these.-More closely allied to feldspar is the substance from Krieglach in Tyrol (Blauspath, Wern.), which was formerly considered as a variety of compact feldspar; near which is placed the azurite of Vorau and of Salzburg, massive and crystallized.-In this table-case also begins the suite of specimens of feldspar, which is continued in the next case; specimens of compact feldspar, among which are, the red variety from 
Sweden, frequently mistaken for hornstone; the saLOoN. weiss-stein of Werner; the feldspath compacie NaT. HIsT. tenace of Haïy, which is the same as the jade of Saussure, called by some saussurite, \&c.

(Case 12.) In this glass case are deposited the different varieties of the Labrador feldspar, the nakerfeldspar, or adularia, and the common feldspar.Among the specimens of Labrador jeldspar (more properly called opalescent feldspar, being remarkable for the beautiful play of colours which it exhibits) are scveral from the transition syenite of Laurwig in Norway.-The adularia (which stands in the same relation to common feldspar, as rock crystal to common quartz) is principally found on Mount St. Gothard, but not in the valley of Adula, from which its name is improperly derived:-this variety when cut on cabochon (such as the stone set in a ring) is commonly called moon-stone; modifications of crystals of this variety.-Common feldspar, variously crystallized and massive, among the latter of which may be particularized the fine green variety from Siberia, called Amazon stone; feldspar with imbecided fragments of quartz (graphic stone) from Siberia, \&c.- To these are added a few specimens of disintegrated feldspar, which passes into porcelain earth. - The chicastolite or macle, placed in this table, is referred by Werner to feldspar, uncer the name of hollow spar.-As intermediate between the contents of this and those of the 
SALOON. next case may be considered the leucite (amphigène NaT. Hrst. of Haüy), of which this case contains several crystals belonging to the trapezoildal modification, in their fresh and altered state, both loose and imbedded in lava.

(Case 13.) is principally appropriated to the substances of the garnet tribe. Among the more remarkable varieties of the noble garnet is that in curved-lamellar concretions, found massive in Greenland.-The pyrope, or Bohemian garnet, in rounded grains, \&c.-The conmon garnet, the predominant colours of which are brown and green: among these may be mentioned the variety which, from its resemblance to rosin, is called colophonite. To this also belongs the elegant variety from Kamschatka, denominated grossular, on account of the resemblance which its separate crystals bear to a gooseberry.-Trapezoidaland emarginated crystals of the black garnets, called melanite, found particularly in the neighbourhood of Frascati.-The allochroite, also called splintery garnet, from Drammen in Norway.-The aplome, whose dodecahedral crystals differ from those of the garnet in being streaked in the direction of the short diagonal of their rhomboidal planes.-The cinnamon-stone from Ceylon, a mineral, which was supposed to contain zirconia, till a more accurate analysis proved it to be a substance nearly allied to garnet and vesuvian : some polished pieces of the same, being the true hyacinth. 
-Among the specimens of vesuvian or idocrase, SALOON. the more conspicuous are the large beautiful cry- $\mathrm{Nar}_{\mathrm{A} . \mathrm{H}} \mathrm{H}_{\mathrm{s}}$. stals (the unibinaire of Haïy) discovered by Laxmann on the banks of the Vilui in Kamschatka, imbedded in a steatitic rock; those from Vesuvius, where this substance occurs accompanied by other volcanic ejections, have, in Italy, obtained the trivial names of volcanic gems, hyacinths and chrysolites. -In this case are also deposited, though not very closely allied to the garnet tribe, the staurolite (called grenatite in Switzerland) : besides several varieties of the cruciform and other crystals from Britany, we have modifications of the simple crystals in mica-slate from St. Gothard, accompanied by prisms of kyanite perfectly similar to those of the staurolite, and sometimes longitudinally grown together with them.

(Case 14.) The contents of this table-case are:-Chrysolite and olivine (péridot of Haüy), the former crystallized, and in cut and polished pieces ; the latter as grains, in basaltic rocks and separate: among these is some of the olivine-like substance found in the cells of the Siberian meteoric iron (Case 32.)-The substances which have been described under the names of thallite, arendalite, akantikone, delphinite, are Haüy's épidote, and Werner's pistacite $:$ of which several specimens are deposited in this case. Among these is also the violet manganesiferous epidote, referred by some to the ores of manganese.-Zoisite.-Axinite, variously 
SALOON. riously crystallized, from Dauphiné, \&c.-The NaT. HIst. pyroxene tribe, comprising the augite, in separate crystals and imbedded in Vesuvian lava, together with groups of well defined crystals from Arèndahl in Norway, where this substance occurs in primitive rocks, and the granular augite or coccolite; the varieties of diopside (now pyroxene) called alalite and mussite; the salite or malacolite, a species perfectly distinct from the common augite or pyroxène.-With these is placed the ilvaite, a mineral substance from the island of Elba, which is known also by the absurd names of jenite and yenite. - The remaining substances in this case relate to the hornblende or amphibolic mineraIs; which are continued in the two next cases: basaltic hornblende from Vesuvius, common hornblende, \&c.

(Case 15 and part of 16.) Continuation of amphibolic minerals: only a few specimens of that widely diffused substance, the common hornblencie, could be deposited in this part of the collection. Between this and the substance now best known by the name of diallage (in the adjoining and opposite case, No. 16), are placed the hypersthene of Haity (Labrador homblende of Werner) and the anthophyilite, a substance from Kongsberg in Norway, nearly allied to them.-The actinote or strahlstein, of which we have the common, glassy, and fibrous varieties, likewise passes into substances contained in the opposite glass case, especially the amianthoide from Oisans and the fibrous actinote, which is 
closely allied to some varieties of common asbest. SALOON. The tremolite (formerly grammatite of Haïy, but NaT. HIsT. now referred by this mineralogist to his amphibole): among the specimens of this substance are, the fine fibrous variety, not unlike in appearance to some varieties of asbest in the opposite glass case; glassy tremolite in dolomite and granular limestone (see the adjoining table-case, No. 21).

(Case 16.) Asbest and amianth, with other related substances: among these may be observed specimens illustrative of the transition from a very close to a loose fibrous structure; various specimens of the flexible asbest or amianth, with some antique incombustible cloth, paper, \&c. made of it; the varieties called mountain wood, mountain cork, or nectic asbest, \&c. separate, and in combination with other substances.-As bordering on the varieties of actinote in the adjoining opposite glass case, we have here the diallage, the green variety of which, called also smaragdite, is considered by Werner as a granular variety of actinote: in combination with saussurite (a variety of compact feldspar) it constitutes the verde di Corsica. - In its vicinity is also placed the axe-stone, or Punamu-stone, thus called after one of the New Zealand islands, where the natives make hatchets, idols, \&c. of it: it is generally considered as a variety of jade.

(Case 17.) This case is occupied by the micaceous and talcose, substances.-Among the varieties 
SALOON. of mica or glimmer, may be specified those that exNaT. HIST. hibit perfectly transparent crystals; the beautiful red and yellow varieties, together with those of a metallic lustre: diverging-radiated mica, \&c.Pinite (micarelle of Kirwan).-Lepidolite; with which is placed a specimen of what is considered as compact lepidolite.-Intermediate between mica and talc, is the chlorite, among the varieties of which are the earthy, common, foliated, and the slaty: the last of these, with octohedral magnetic ironstone, bitterspar, \&c.-Of talc we have the common or Venetian, which enters the composition of cosmetics, and the indurated talc: to the former of these may also be referred the beautiful green variety from Siberia, composed of distinct groups of small diverging-radiated laminæ.-Potstone or ollite, the lapis comensis of the ancients, from Como in the Milanese, where it is turned on the lathe into most durable culinary vessels.-In this case is also placed a substance from New York, which has very much the appearance of white laminar talc, but is a hydrate of magnesia .

(Case 18.) contains steatitic substances.- $\mathrm{No}$ ble serpentine, which, in combination with primitive limestone, constitutes the marmo verde antico; common serpentine, among the varieties of which are best known those from Bareuth and from Zöblitz in Saxony, where they are manufactured into vases and various other articles; serpentine with 
garnets, magnetic ironstone, asbest, slaty talc, \&c. -Varieties of steatite, among which the most remarkable are those from Cornwall, that of a yellowish green colour from Greenland, that from Göpfersgrün in Bareuth, with small crystals of other mineral substances, converted into, and forming part of, the massive steatite.-To these are added some substances which are allied to the preceding, though different from them with regard to their chemical composition; such as the agalmatolite of Klaproth (bildstein of Werner, talc glaphique of Haüy), employed by the Chinese for carving images, vessels, \&c.-The keffekil or meerschaum, from Natolia, of which pipe bowls are made; and a related substance, called keffekilite by Dr. Fischer, who discovered it in the Crimea.-Lithomarge, the more remarkable varieties of which are, that of a reddish yellow colour, from Rochlitz, in porphyry; the fine purplish blue variety from Planitz, called terra miraculosa Saxonica by old writers.Fuller's earth.-Bole; green earth, \&c.

(Cases 19 and 20.) In these and the threefollowing table-cases are deposited the various carbonates of lime.-Crystallized carbonate of lime or calcareous spar; specimens illustrative of the cleavage, supernumerary joints, colour, \&c. ; primitive rhombohedron (rhomboid) ; various secondary rhombohedrons : amongst these the most common, but not the least striking, is the inverse rhombohedron, so called from 
SALOON. from being as it were an inversion of the primitive;

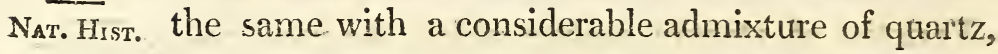
commonly called crystallized sandstone of Fontainebleau. Prismatic and pyramidal modifications of the same, among the former of which are the beautiful varieties from the Hartz, Salzburg, \&c.*

(Case 21.) The same continued:-This case contains specimens of the lamellated varieties of carbonate of lime called slate-spar and aphrite: tabular spar with garnets and cinnamon stone; granular and compact limestone (marbles); massive magnesian limestone, called dolomite, and (contiguous to it, in the opposite case) the crystallized magnesian limestone, called bitterspar, in chlorite slate, \&c.-Fibrous limestone, the finest variety of which is that from Cumberland, and Andrarum in Sweden, with pearly lustre, which has obtained the name of satin spar.

(Case 22.) Various specimens of stalactical limestone, some varieties of which bear the name of alabaster in common with compact gypsum; the peculiar variety called pea stone, from the hot springs of Carlsbad in Bohemia, and the white variety found in the bed of a small river near Tivoli, and known by the name of confetti di Tivoli.-

* For a greater variety of the modifications of crystallized carbonate of lime see the British Collection, especially Derbyslire and Cumberland.

Calca- 
Calcareous tuf; to which are added some casts of SALOON. medals, made at the baths of San-Felippe in 'Tus- NaT. $\bar{H}_{\text {Ist. }}$ cany, where moulds of medals, gems, \&c. are placed in convenient situations to receive the calcareous deposition.-As a continuation of the compact limestone in the last case, we have in this, the shell limestone, the most esteemed variety of which is that from Carinthia, called lumachella or fire marble; and some varieties of anthraconite called also madrepore stone from a distant resemblance this substance bears to some petrifactions of the order of corals; fetid limestone, \&c.

(Case 23.) This case is occupied by suites of brown spar and of arragonile. Among the specimens of the former are many of the scarce fibrous varieties, which were formerly referred to common fibrous limestone; among the latter are Werner's columnar and acicular arragonite, as also fine specimens of the remarkable coralloid variety from Eisenertz in Styria, formerly called flos fervi.

(Case 24.) contains the fluates of lime. Among the numerous varieties of fluor spar may be particularized the rose-coloured primitive crystals from Chamouni; the chlorophane from Siberia; the varieties called fortification fluor; earthy and compact fluor, \&c. To these are added specimens of yttrocerite, being a fluate of lime, yttria and cerium ; as also of a substance composed of fluate of yttria and oxide of cerium, with only a small portion of lime, 


\section{4}

SALOON. but in which is often found a fluate of a new earth, Мат. Н̈sт. to which professor Berzelius has given the name of thorie.

(Case 25 and part of 26 ) contain the remaining calcareous salts, $2 i$. the phosphates and sulphates of lime. Among the phosphates may be seen several very scarce and interesting crystallizations of Werner's apatice (such as the large crystal from St. Petersburg); the rariety called asparagus-stone; the Norwegian apatite, called noroxite; also the phosphorite, or earthy and compact phosphates of lime, and the pulverulent variety of the same, inown by the name of earth of Marmorosh, and which was formerly considered as fluate of lime.-The sulphates of lime are divided into selenite or sparry gypsum, of which several regularly crystallized, acicular and lenticular varieties are deposited; fibrous gypsum, with silky lustre; foliated and compact gypsum, to which latter belongs the stalagmitical variety from Guadaloupe; and the earthy gyosum, to which may be referred Haity's niviform variety of sulphate of lime.-The remainder of this case is occupied by the anhydrous sulphate of lime, or the cube spar and muriacite of Verner, the compact variety of which is, in some parts of Italy, known by the name of bardiglione.

(Case 26.) Besides the continuation of the phosphates of lime, and the specimens of borate of lime and silica (to which latter belong Esmarck's datholite 
and Hausmann's botryolice, two scarce Norwegian SALOON. minerals), this case contains all the subspecies and NaT. Hist. varieties of sulphate of barytes, vis. the straight lamellar, variously crystallized; the curved lamellar barytes; the columnar and prismatic barytes; and the radiated, also called Bolognese spar, from Monte Paterno near Bologna, and from Bavaria; the compact, including the fetid barytes or hepatite, \&c.

(Case 27.) Barytic salts continued. Among the specimens of carbonate of barytes, or witherite, may be particularized the beautiful groups of double sixsided pyramids, and those of six-sided prismatic crystals.-Strontian salts : carbonate of strontian, also called strontianite, in prismatic and acicular crystals, which have sometimes been mistaken for arragonite. -Among the sulphates of strontian (felestine of Werner) the more remarkable specimens are, the splendid groups of limpid prismatic crystals: on sulphur, from Sicily; the acicular variety in the hollows of compact sulphate of strontian, from Montmartre; the same in fissures of fint; the radiated and fibrous celestine, \&xc.-The remainder of this case is occupied by some other saline stony substances, vis. borate of magnesia, or boracite, in separate crystals, and the same imbedded in gypsum; subsulphate of alumine, from Halle in the territory of Magdeburg, which was formerly considered as pure alumine; fluate of soda and alumine, or cryolite, pure and intermixed with brown iron-

D 2 stone, 
SALOON. stone, galena, \&c.; mellite or honey stone, which $\mathrm{N}_{\text {AT. HIst. }}$ is said to be geognostically related to amber, but is a mellate of alumine.-Glauberite, imbedded in white and blue rock salt, \&c.

(Case 28.) contains various saline minerals, among the more remarkable of which are the fibrous sulphate of magnesia and soda, from Calatyud in Arragon, and the blue salt with Glauberite from Aranjuez, in Spain.

In the glazed table-cases and drawers on the right hand side of the principal entry from the first room into the Saloon, are deposited the Metallic ores.

(Case 29.) The ores of platina, gold, and mercury.-Platina in grains from Peru and Brazil: the latter mixed with grains of grayish yellow gold. Palladium.-Iridium.-Native gold subdivided into pure and alloyed gold; the former chiefly massive and as grains (from-Guinea, Bengal, Sumatra, ) and in brown iron-stone, in quartz, with needle ore (acicular sulphuret of bismuth, \&c.) from Siberia; the alloyed gold (principally from Transylvania) crystallized in minute cubes and octohedrons variously aggregated, in reticular plates, \&c.-The ores of mercury in this case are:-the sulphurets, consisting of dark red cinnabar (by far the more common variety) massive, crystallized, and in combination with various mineral substances; the bright red cinnabar (native vermilion, much esteemed by painters); the hepatic mercurial ore from Idria, 
compact and slaty; the former also with petrifac- SALOON. tions (coral ore); muriate of mercury, or corneous NaT. Нısт mercury, with native quicksilver, \&c.

(Case 30.) This case contains (besides some ad. ditional specimens of gold and mercurial ores, among the latter of which is the scarce native amalgam, crystallized and globular, ) the ores of silver, between which and the ores of gold are placed, the alloy, called clectrum, from Smeof in Siberia, and the auriferous silver from Kongsberg in Norway, both being a mixture of gold and silver in different proportions. Other alloys of silver are the scarce antimonial silrer from Wolfach in the Black Forest, and the arsenical silver from Guadalcanal in Andalusia.Among the numerous varieties of mative silver may be particularized the various imitative forms ix which it occurs, such as tooth-shaped, wire-shaped, dendritical, moss-like, reticular, \&c., many of which are aggregations of minute crystals.-Common sulphuret of silver, or vitreous silver; massive, crystallized, and in other external forms, among which are the laminar and capillary.-Brittle vitreous silver, of which some specimens are also deposited in the following glass case.-White silver ore.

(Case 31.) The ores of silver contained in this case are the dark and light-coloured varieties of red or ruby-silver ore, massive, crystallized, and in combination with various substances; the black silver ore, or sooty silver, which has not been ana- 
SALOON. lysed; - the muriate of silver, called also corneous Nar. Hrst. silver and horn ore, of various colours, amorphous, botryoidal, in laminæe, and crystallized in minute cubes and octohedrons; - the very scarce carbonate of silver, also called grey silver ore, from AltWolfach in Suabia, \&c.-In this case begin the numerous copper ores: among the specimens of native copper (which, like the native silver, presents a great variety of forms, besides the crystallized, such as dendritic, filiform, \&c.) may be specified the mass from Hudson's Bay, found by Mr. Hearne and described by him in his journal.

(Case 32.) Ores of copper continued; common sulphuret of copper or vitreous copper, variously crystallized, foliated, compact, \&c. To this are also commonly referred the oblong, scaly, secondary fossils, known by the name of Frankenberg corn ears, which occur in the bituminous marl-slate of Frankenberg in Hessia, and are principally composed of vitreous and grey copper.-The variegated copper. ore, easily known by the reddish colour of its fractured planes, massive and foliated.-The grey copper ore (fahl ore), crystallized, massive, and disseminated in various substances.

(Case 33.) Ores of copper continued: yellow - copper or copper pyrites, the most common of all the ores of this metal: among these is also the pale yellow, fine grained variety, called hematitiform and blistered copper pyrites.-Red or ruby copper 
ore, compact, foliated, and fibrous; one of the more SALOON. remarkable is the bright red capillary variety from NAT. Hrs? Rheinbreitenbach, in Nassau. To these are added a few specimens of what is called tile-red copper, or tile ore, a mixture of red copper ore and brown iron ochre.

(Case 34.) Ores of copper continued: black copner massive, and as superficial covering of other copper ores.-Cribonates of copper: crystallized. radiated blue or azure copper, from Chessy and the Bannat, combined with various substances, and earthy varieties of the same, some of which (called mountain-blue) have been used as pigments.Crystals passing from the state of blue copper into that of green carbonate (cuivre carbonaté bleu épigène Haïy.)-Green carbonates of copper; among which are the beautiful varieties of fibrous malachite of velvety appearance, in acicular crystals, with carbonate of lead, \&c.

(Case 35.) Ores of copper continued: among the specimens of compact malachite, the most beautiful and characteristic are those from the Gumashevsk and Turja mines in the Ural mountains.Anlydrous carbonate of copper.-In this case is also placed the copper-green of Werner, by some called chrysocolla, a substance often confounded with common green carbonates of copper, but which contains much silica.-To the silicates of copper may likewise be referred the dioptase, a very scarce

substance 
SALOON. substance from Siberia, also called emerald copper, Nat. HIst. on account of its pure green colour; and the very scarce sky blue velvet copper ore.-Phosphate of copper from Nassau and Hungary. - Muriate of copper, crystallized and laminar: to which also belongs what is called green sand of Peru, or atacamite, from being found in the desert of Atacama, between Chili and Peru, as sand of a small river. The rest of this case is occupjed by the principal varieties of the different arseniates of copper, namely, the foliated arseniate, or copper mica, the lenticular arseniate, or lentil ore, and the olive ore of Werner, which are formed into five distinct species by some mineralogists; to which is added a specimen of the martial arseniate of copper. (A greater variety of arseniates of copper will be found in the collection of British minerals : Cornwall.)

(Case 36.) contains ores of iron, vis. native iron, arsenical pyrites (also called arsenical iron, and mispickle, a variety of which is argentiferous, and common iron pyrites, with its various crystalline modifications derived from the cube, which is either smooth or striated. The most interesting specimens deposited in this case are those of native iron, and the stones called ärrolites, because they have fallen from the atmosphere, or meteoric stones, because they are by some supposed to be depositions from meteors. The specimens of the former are, 
-native iron from Gross-kamsdorf, in Saxony;SALOON. two small polished pieces of the mass found in NAT. Hist. Southern Africa, which weighed about 250 pounds, and is now in the cabinet of Haarlem;-fragment of the iron from Senegal;-specimens of the native iron from Otumpa, in the Gran Chaco Gualamba, in South America, described by Don Rubin de Celis, who estimated the weight of the mass to be about 300 quintals, or 15 tons;-a large piece detached from the celebrated mass of Siberian native iron, which was discovered by Pallas on the summit of a hill between Abakansk and Belskoi Ostrog on the banks of the Jenisey, where is was considered by the Tartars as a sacred relic: the mass originally weighed about 1,680 pounds; - a piece of the large mass from Ellenbogen, in Bohenia, and another of that found on Collina di Brianza; in Milan, which has been described by Chladni and analysed by Gelien. Of meteoric stones (classed with native iron, because they all contain this metal, alloyed with nickel) the following areplaced in chronological order :-a large fragment of the stone which fell at Ensisheim, in Alsace, Nov. 7 th, 1492, in the presence of the emperor Maximilian, then king of the Romans, when on the point of engaging with the French army: this mass, which weighed 270 pounds, was preserved in the cathedral of Ensisheim till the beginning of the French revolution, when it was conveyed to the public library of Colmar;-one of 
S.ALoox. the many stones which fell, July $3 \mathrm{~d}, 1753$, at Plaun, Nat. Hist. in the circle of Bechin, Bohemia, and which contain a great proportion of attractable iron;-specimens of those that were seen to fall at Roquefort and at Juliac, in the Landes of Gascony, July 24th, 1790; -one of a dozen of stones of various weights and dimensions that fell at. Sienna, in Tuscany, Jan. 16th, 1794 ;-fragment of the meteoric stone, weighing 56 pounds, which fell near Wold Cottage, in Yorkshire, Dec. 13th, 1795 ;-fragment of a stone of 20 pounds, which fell in the commune of Sales, near Villefranche, in the department of the Rhône, March 12th, 1798 ;-specimens of stones fallen near the city of Benares, in the East Indies, Dec. 19th, 1798;-an entire and a broken specimen of the meteoric stones of which a shower descended at Aigle, in the department of the Orne, April 26th, 1803 ;-fragment of one of those that were seen to fall at Weston, in Connecticut, Dec. 14th, 1807;two meteoric stones with shining black surfaces, fallen May 22d, 1808, at Stannern, in Moravia ;two fragments of the Tipperary aërolite which fell in August 1810: it contains quartz globules of a green colour owing to oxide of nickel;-a fragment of one weighing 66 pounds, which fell August 5 th, 1812, near Chantonnay, in the Vendée.

(Case 37.) Ores of iron continued:-radiatea pyrites of Werner (fer sulfuré blanc Haïy), a substance very subject to decomposition: to this belong 
long most of the varieties of what is called lenticular SALOON. and coxcomb pyrites, as also the globular pyrites of a radiated texture.-The hepatic or liver pyrites Nat. Hist. of Werner, very distinct from what French mineralogists call fer sulfuré hépatique, which latter is decomposed common and radiated iron pyrites and sometimes brown iron stone.-Magnetic pyrites, which is nearly allied to the preceding species; massive and crystallized in six-sided prisms. - Oxides of iron: magnetic iron stone, massive, of various grain, compact, crystallized, in serpentine, chlorite slate, \&c. ; ore which yields the woots, a very hard kind of iron from the East Indies; magnetic iron sand.

(Case 38.) Oxides of iron continued.-Specimens of specular iron, or iron glance, among which those from the island of Elba are remarkable on account of their beautiful iridescence and play of colours ; variety in large laminar crystals, appearing like polished steel, from Stromboli, \&c. ; the micaceous iron ore of Werner, belonging partly to this species, partly to the scaly red and brown ironstone; among the most remarkable specimens of which is that in delicate, trąnsparent tables of a blood red colour, from Nassau-Siegen; that in scales coating the cells of lava; a shining brownish black variety used as hair-powder by the Bootchuana natives beyond the Great River, South Africa, \&c. - The different varieties of compact red iron-stone, and of red hematite. 
SALOON.

NaT. HIST.

(Case 39.) Ores of iron continued:-liydrous oxides of iron, comprehending IVerner's ochrey and compact brown iron-stone, and brown hematite, together with several varieties of argillaceous or clay iron-stone, such as common, columnar, pisiform, reniform clay iron-stone, meadow ore, \&c. - Carbonate of iron, or spathose iron ore, the primitive form of which has lately been ascertained, by $\mathrm{Dr}$. Wollaston, to be different from that of carbonate of lime: crystallized, massive, in combination with other substances.

(Case 40.) contains the remaining ores of iron and those of manganese, a metal which stands in close geognostical relation with iron.-Arseniate of iron, which occurs only crystallized, chiefly in cubes, whence Werner's name of cube ore. [See British Collection: Cornwall.] Chromate of iron, among the specinnens of which is one from Baltimore, in which this substance is intermixed with talc coloured purple by chromic acid.-Murate of iron, called pyrosmalite, from Sweden.-Phosphate of iron, crystallized, massive, and pulverulent: among the specimens of the latter are, the massive variety from New Jersey, and several earthy varieties, in zlay, wood, peat, \&c.-The pitchy iron ore of Werner, from Limoges, may be referred to phosphate of manganese. - Ores of manganese: radiated grey manganese, from Ihlefeld, \&c. some varieties of which resemble the radiated antimony 
in the disposition of their acicular crystals ; foliated SALOON. grey manganese: compact grey manganese of various forms, botryoidal, tubercular, reniform, \&c. ; earthy grey manganese, a remarkable variety of which is the black wad of Derbyshire and Devonshire, which has the property of inflaming spontaneously when mixed with linseed oil.-Silicatc of manganese, \&c.

(Case 41.) In this and the two following cases are contained the ores of lead; the most common and useful of which is the sulphuret of lead, or $g$ \&Lena: the specimens here deposited include various modifications of crystals, detached, and grouped together, in combination with blende, pyrites, and many other substances; galena of various grain, massive and disseminated; galena of corroded appearance, decomposed and regenerated; the compact and specular variety, called slickenside by the Derbyshire miners.-IVith these is also placed the antimonial sulphuret of lead, or triple sulphuret of lead, antimony, and copper, called Endellion by Count Bournon. [See British Collection : Cornwall.]

(Case 42.) Ores of lead continued:-the more prominent specimens in this case are those of carbonate of lead, or white lead, among which may be particularized the laminar varieties, the beautiful modifications from Siberia, and the crystallized acicular white lead from the Hartz, accompanied with 
SALOON. green and blue carbonates of copper; the fine light Nat. Hist. blue variety coloured by copper, \&c.; - the black lead ore of IVerner, which appears to be merely a variety of the white lead ore.-Phosphates of lead, which are divided by Werner into brown lead ore and green lead ore. Among the specinens of the brown phosphate, the most remarkable are the large sixsided prisms from Huelgoet in Britany, \&c.

(Case 43.) Ores of lead continued:-green phosphate, massive, botryoidal, spicular, \&c.; variously crystallized; of various shades of green, passing into greenish white, into yellow and orange; with ferruginous quartz, straight foliated barytes, \&c. from Scotland, Freiberg in the Brisgau, \&c.; - Molybdate of lead, or yellow lead ore; massive, lamelliform, and crystallized ; on compact limestone, \&c. chiefly from Bleyberg in Carinthia.The specimens of chromate of lead, or red lead ore, deposited in this case, are particularly beautiful and instructive; the accompanying substances are green lead ore, and sometimes small greenish brown crystals of a substance, the component parts of which are the oxides of lead and of chrome: the gangue stone, in which the red lead occurs in the gold mines of Beresof, is a lind of micaceous rock mixed with particles of quartz and brown iron stone.-Murio-carbonate of lead, or horn lead, the crystallized varieties of which have hitherto been observed in Derbyshire only. [An interesting 
interesting suite of crystals of this scarce mineral SALOON. substance will be found in the British Collection: NAT. Hist.

Derbyshire.] - Sulphate of lead, called native leadvitriol by Werner, crystallized and massive.-Lead carth, indurated and friable, of various colours; its different varieties appear to be related to carbonates, phosphates, and sulphates of lead: to which latter also the reniform lead ore (blei-niere of Werner) from Siberia appears to belong: some varieties of lead earth are oxides. Near to these is also placed the native minium, from Hessia, first described by $\mathrm{Mr}$. Smithson, and varieties of the same from Siberia; all of them probably produced by the decay of galena.

(Case 44.) Ores of zinc. Among the many varieties of sulphuret of zinc, or blende, may be particularized those relative to colour, viz. the yellow, the brown, and the black blende of Werner; the first of which is generally most pure, while the two others contain a portion of iron; the variety called testaceous blende (schaalen-blende), the most characteristic specimens of which are from Geroldseck in the Brisgau, contains, besides iron, a portion of lead. - The other ores of zinc in this case are those of a sparry appearance, commonly called calanine, which constitute three different species, viz. the electric or siliceons calamine; the common calamine, or native carbonate of zinc; and the red oxide of zinc: the specimens of the two former species include various 
SALOON. rious crystalline and other forms, among which are $\mathrm{NaT.} \mathrm{H}_{\mathrm{HST}}$ the pseudomorphous crystals of carbonate of zinc, derived from modifications of calcareous spar.

(Case 45.) Ores of tin, of which we have the sulphuret of tin, or tin pyrites, and the oxides, which are divided into common tin stone, and wood tin:tin pyrites, hitherto only found in Cornwall, nearly pure, mixed with copper pyrites, \&c. ;-among the specimens of common tin stone are, the regular and macled crystals, the pebble-like, and granular tin stone (shoad tin, stream tin, grain tin, \&c.;) and the greyish white crystals, resembling scheel-ore, or tungstate of lime; the tin stone from Finbo, in Sweden, which contains oxide of tantalum.-The ores of tungsten, which generally accompany those of tin, are-wolfram (schéelin ferrugineux Haiiy), crystallized and massive, from Bohemia, \&c.; and the tungstate of lime, scheel ore (schéelin calcaire H(iiiy), among the crystallized specimens of which is the primitive acute octohedron from Allemont in Dauphiné.-In this case are also placed the specimens of molybdena, or sulphuret of molybdenum, which should not be confounded with graphite: the yellow powder on feldspar, from Westmania in Sweden, is oxide of molybdenum.

(Case 46.) Part of this case is occupied by the ores of titanium, viz. the oxides, called titanite, brown-ore, brunon, (sphène, and titane siliceo-calcaire Haiiy,) among the varieties of which is that 
in large flat octohedral crystals from Norway, with SALOoN. epidote, \&c. also the variety called, by Saussure, Nar. HIst. rayonnante en gouttière, from St. Gothard, on feldspar, with chlorite, \&c.-Titan-shorl, also called rutile; massive, crystallized, and fibrous, to which latter belongs the variety with golden tarnish, from Moutier, near the Montblanc; the acicular crystals of rutile in rock crystal, \&c. ; the ferriferous oxides, some varieties of which may be considered as titaniferous oxides of iron, and to which may be referred the black sand called menachanite, and the iserine, in loose grains and imbedded;-specimens of anatase, or octohedrite, from Dauphiné ;- the scarce substance called craitonite (crichtonite), by the Comte de Bournon, likewise from Dauphiné, in very acute octohedral crystals, and in thin laminæ.

The remainder of this table case contains the ores of antimony: native antimony, from Allemont, and from Sala in Sweden, some varieties of which are arseniferous;-sulphuret of antimony, or grey antimony (the most common ore of this metal), occurs compact, foliated, radiated, and plumose : the more remarkable among these are the specimens of crystallized radiated antimony in fine groups, especially frum Transylvania; radiated grey antimony with barytes, realgar, \&c. ; the plumose grey antimony, some varieties of which, appearing like delicate wool or down, display a fine iridescent blue, 
sad.oon. yellow, and red tarnish; - red antimony, mostly in Nar. HIst, fine capillary crystals, from Bräunsdorf in Saxony ; -white antimony, crystallized, on galena, \&c.specimens of antimonial ochere on native and grey antimony, \&c.

(Case 47 and part of 48) contain the ores of cobalt and arsenic. The crystals of glant $\approx$-cobalt, which has been frequently confounded with white cobalt, are mostly from Sweden;-a suite of specimens of white cobalt, exhibiting the principal modifications of crystallized and irregular shapes;grey cobalt, principally from Wittichen in Würtemberg;-some specimens of oxides of this metal, viz. the black and the brown or yellow cobalt ochre, the latter of which contains iron;-various specimens of the red cobalt ore, or arseniate, comprising the earthy (cobalt crust) and the radiated (cobalt bloom) varieties, from Saalfeld, Allemont, \&c.Between these and the remaining metallic substances in the adjoining case are deposited the ores of arsenic; native arsenic, (formerly called testaceous cobalt,) in reniform and botryoidal shapes, from Andreasberg, \&c.;-splendid and instructive specimens of the sulphurets of this metal, vir. the yellow orpiment, massive, and in separable, striated, transparent laminæ; and the red orpiment or realgar, perfectly crystallized and massive, and also (in the large specimen in the centre) as colouring matter between the laminæ of straight-foliated crystallized 
crystallized barytes;-specimens of the native oxide SALOON. of arsenic, showing the octohedral form of its pri- NAT. $\bar{H}_{1}$ sT. mitive crystals; near which are placed, on account of their affinity to the other ores of arsenic, the varieties of pharmacolite, which is an arseniate of lime, and might therefore claim a place among the calcareous salts.

(Case 48.) The contents of this case are:-The ores of nickel, among which may be particularized the native nickel from Saxony, which was formerly classed with the ores of iron, under the denomination of capillary pyrites;-the arsenical nickel, called copper nickel;-niekel ochre, which is no oxide, but an arseniate, of nickel. Ores of bismuth : native bismuth, massive, disseminated and dendritic in jasper; to which is added a specimen exhibiting the artificial crystallization of the same, produced by sudden cooling of the melted metal; - sulphuret of bismuth, the bismuth glance of Werner, with which is placed the Siberian needle ore of the same mineralogist, being a triple sulphuret of bismuth, lead, and copper.-Ores of Uran: the protoxide of uranium, called pitch ore, massive, pure and with adhering ochre of the same metal; - the oxide called uran mica or micaceous uran, on account of its foliaceous and thin laminar crystals, in beautiful groups of emerald.green and yellow colours. The ores of tellurium or sylvane, which are divided into native tellurium, white and yellow (containing gold 
SALOGN. and iron); the graphic ore, so called on account of Nат. Нгт. the disposition of its minute laminar crystals into groups that bear a distant resemblance to written characters; and the black or Nagyag ore (commonly alloyed with gold and some lead).-The $c e$ rite or cererite (oxide of cerium) from Bastnaes, in Westmanland, in Sweden.-A specimen of the oxide of chromium, in quartz, discovered by $\mathrm{M}$. Leschevin at Creuzot, in the Department of the Saone and Loire.

ORDER OF THE TABLE CASES IN THE SALOON.
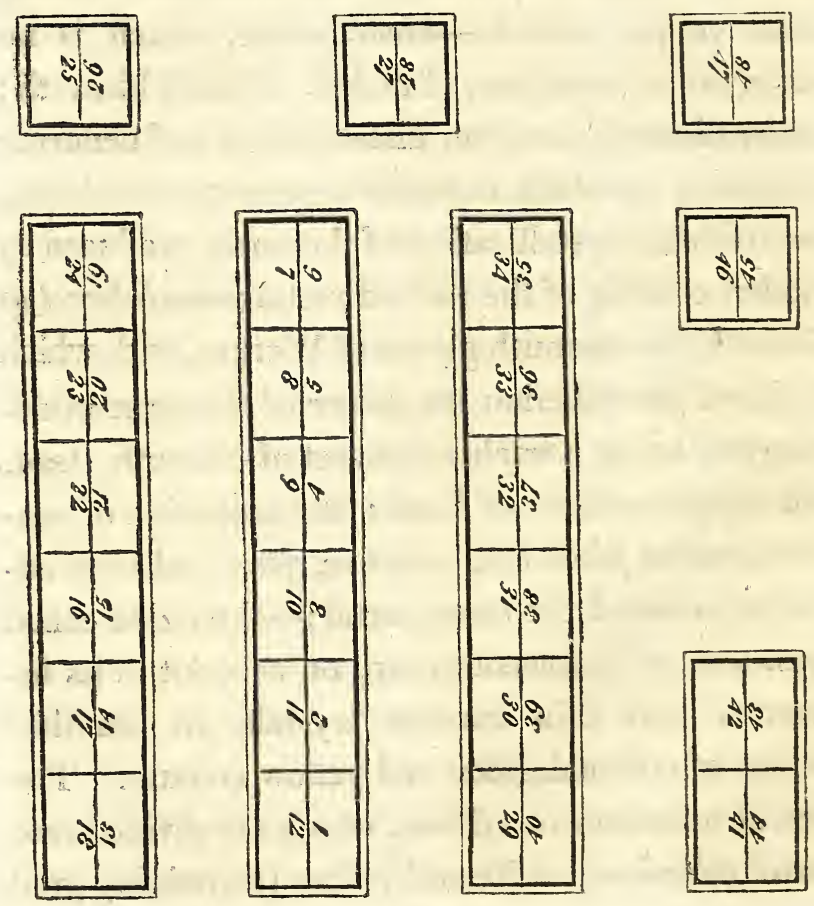


\title{
ALPHABETICAL LIST OF THE MINERALS
}

\section{IN THE SALOON,}

\author{
WITH REFERENCES TO THE TABLE CASES AND THE
}

DIAGRAM.

Actinote, 15

Adularia, 12

Aërolite, 36

Agalmatolite, 18

Agaric mineral, 22

Agate-jasper, 9

Aliclite, 14

Albite, 12

Allochroite, 13

Alum, 28

Alumine, subsulphate of, 27

Amalgam, native, 30

Amber, 1

Amethyst, 4

Amianth, 16

Amphigène, 12

Antimony, native and Boracite, 27 ores of, 46

Analcime, 10

Anatase, 46

Andalusite, 2

Anhydrite, 25

Anthophyllite, 16

Anthracite, 1

Anthraconite, 22

Apatite, 25

Aphrite, 21

Aplome, 13

Apophyllite, 10

Arragonite, 23

Arsenic, ores of, 46,47 Cat

Asbest, 16

Asparagus stone, 25

Asphaltum, 1

Atacamite, 35

Avanturino-quartz, 6 Chabasite, 10

Aranturino-quariz, 6-Chalk, 22

Augite, 14

- Borax, native, 28

Botryolite, 26

Bournonite, 2

Brown coal, 1

Brown ore, 46

Brown spar, 23

Brunon, 46

Cacholong, 7,8

Calamine, 44

Calcareous spar, 19,20 Corundum, 2

Calcedony, 6

Carnelian, 7

Antomolite, 2
Chromium, oxide of, 47

Chrysoberyl, 23

Chrysocolla, 35

Chrysolite, 14

Chrysoprase, 7

Cinnabar, 29

Cinnamon stone, 13

Clay-iron stone, 39

Cobalt, ores of, 46,47

Cobalt, sulphate of, 28

Cobalt-vitriol, 28

Coccolite, 14

Colophonite, 13

Crichtonite, 46

Cymophane, 3

Copper, native, 32

—_ oxides of, 33,34

_- salts of, 34,35

— sulphurets, 32,33 seleniuret, 34

Copper-black, 34

Copper-blue, 34

Copper glance,

Copper-green, 35

Copper-mica, 35

Copper-nickel, 47 .

Copper-pyrites, 33

Copper-vitriol, $2 S$

Cross-stone, 11

Cryolite, 27

Cube ore, 40

Cubicite, 10

Datholite, 26

Diamond, 2

Diaspore, 2

Dichroite, 9

Diallage, 16

Diopside, 14 
SALOON. Dioptase, 35

Dipyre, 10

Nat. Hist. Disthene, 3

Dolomite, 21

Dysodile, 1

Elæolite, 11

Electrum, 30

Emerald, 3

Emerald-copper, 35

Emery, 2, 37

Eudellion, 41

Epsom salt, 28

Epidote, 14

Euclase, 3

Feldspar, 11, 12

Fibrolite, 2

Fish-eye stone, 10

Flint, 7

Flinty-slate, 8

Fluor spar, 24

Fullers' earth, 18

Gadolinite, 2

Galena, 41

Garnet, 13

Gehlenite, 12

Glance-cobalt, $4 \overrightarrow{7}$

Glauberite, 27

Glauber salt, 28

Gold, 29

Graphite, 1

Green earth, 18

Grenatite, 13

Grossular, 13

Gypsum, 25

Harmotome, 11

Haüyne, 11

Heavy spar, 26

Heliotrope, 7

Hematite, red, 38

Hepatite, 26

Hepatic ore, 29

Honeystone, 27

Hornblende, 14, 15

Horn lead, 43

Horn silver, 31

Horn stone, 8
Hvacinth, 2, 13

Hyalite, 6

Hydrargillite, 2

Hypersthène, 16

Jade, 11

Jasper, 9

Jasp-opal, 8

Jet, 1

Ichthyophthalmite, 10

Idocrase, 13

Ilvait, 14

Indianite, 12

Iolite, 9

Iridium, 29

- Iron, arsenical, 36

- hydrates of, 39 Madrepore stone, 22

- meteoric, 36 - Magnesia, hydrate of, 17

- native, 36 - salts of, 27,28

- oxides of, 37, 38 Magnesia and soda,

_- salts of, 28, 39, sulphate of, 28

$40 \quad$ Malachite, 34, 35

- , sulphurets of, 37 Manganese, ores of, 40

Iron flint, 56

Ironglance, 38

Iron-mica, 38

Iron ore, pitchy, 40

Iron-pyrites, 37

Iron-sand, 37

Iron-spar, 39

Ironstone, brown, 39

- magnetic, 37 -Mercury, native and

Iron-rit, 38

Iserine, 46

Keffekilite, 18

Kohlenblende, 1

Kyanite, 3

Labrador-spar, 12

Labrador Hornblende, 16

Laumonite, 10

Lazulite, 11

Lead, native, 43
Marl, 22

Meerschaum, 18

Meïonite, 11

Melanite, 13

Melilite, 12

Mellite, 27

Menachanite, 46

Menilite, 8 ores of, 29,30

Mesotype, 10

Meteorite, 36

Mica, 17

Minium, native, 43

Mispickel, 36

Molybdenum,oresof, 45

Moroxite, 26

Muriacite, 25

Mussite, 14

Nagyag-ore, 47

Naphtha, 1

Natrolite, 10

5 - - oxides of, 43 - Needle-ore, 47

- - salts of, 42,43 Needle stone, 10

-, sulphurets of, 41 Nickel, alloy's and oxLead-earth, 43 
Nitre, native, 28

Obsidian, 9

Octohedrite, 46

Olive ore, 35

Olivine, 14

Opal, 8

Orpiment, 47

Orthite, 2

- Palladium, 29

Pea stone, 22

Pearl sinter, 6

Pearl stone, 9

Petroleum, 1

Pharmacolite, 47

Phosphorite, 25

Pimelite, 7

Pinite, 17

Pistacite, 14

Pitch ore, 47

Pitchstone, 9

Platina, 29

Pleonaste, 2

Potash, nitrate of, 28 Slate spar, 21

Pot stone, 17

Prase, 5

Prehnite, 11

Pumice, 9

Pycnite, 3

Pyrites, common, 37

Pyrope, 13

Pyrophysalite, 3

Pyrorthite, 2

Pyrosmalite, 40

Quartz, 5

Quicksilver, native, 20
Realgar, 47

Retinasphaltum, 1 Talc, 17

Rock crystal, 4

Rock salt, 28

Rockwood, 16

Rubellite, 3

Ruby, 2

Ruby-copper, 33

Ruby-silver, 31

Rutile, 46

Salite, 14

Sapphire, 2

Scapolite, 11

Scheel-ore, 45

Selenite, 25

Serpentine, 18

Shorl, 3

Siderite, 5

Silver, native and oresw Wad, 40

$$
\text { of, } 30,31
$$

Silver-block, 31

Silver-glance, 30

Sinter, 6

Slate spar, 21

Sphene, 46

Spinel, 2

Spodumen, 12

Staurolite, 13

Steinheilite, 5

Steatite, 18

Stilbite, 10

Stinkstone, 22

Stones, meteoric, 36

Strontian, salts of, 27 Zinc vitriol, 28

Sulphur, 1
SALOON.

Tantalite, 2

Tellurium, ores of, 47

Tile-ore, 7

Tin, ores of, 45

Titan-shorl, 46

Titanium, ores of, 46

Topaz, 3

Tourmaline, 3

Tremolite, 15

Tungsten, 45

Turquois, 2

Uranium, ores of, 47

Velvet-copper, 35

Vesuvian, 13

Wavellite, 2

Wernerite, 11

Witherite, 27

Wolfram, 45

Wood-opal, 8

Wood-stone, 8

Wood-tin, 45

Yenite, 14

Yttrocerite, 24

Zeolite, 10

Zircon, 2

- Zinc, salts and sulphitlrets of, 28, 44

Zoisite, 14

Nat. Hist. 


\section{EIGHTH ROOM.}

RoomviI. The most interesting part of the collection of

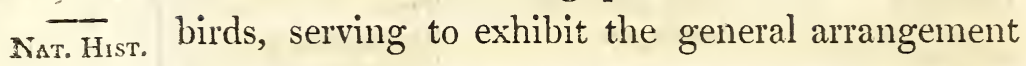
of the animals of that class, is contained in cases round the room.

(Cases 1 and 2.) Accipitres, rapacious birds, or birds of prey; the Californian vulture; a singular sariety of the Pondicherry eagle; horned owls, \&c.

(Case 3.) Various species of parrots, mackaws, and woodpeckers.

(Case 4.) Toucans, barbets, cuckoos, shrikes, Stc.

(Cases 5 and 6.) Grosbeaks, buntings, orioles, swarblers, paradise-birds, king-fishers, \&c.

(Case 7.) Pigeons.

(Cases 8 to 10.) Small African bustard, pheasants, the jungle-cock of India, which some have supposed to be the original stock from whence our domestic fowls have sprung; quails, horned screamer, wood-grouse, partridges, a specimen of the common wild pintado of Africa, adjutant crane, boat-bill, tufted umber, rose-coloured spoonbill, \&c.

(Cases 11 and 12.) Scarlet curlew, scarlet flamingo, American avoset, darters, divers, \&c.

(Case 13.) contains some curious nests and eggs of birds; the soup-nests formed by a species of swallow; 
swallow; the nest of the tailor-bird, \&c. On the roomvir. lowermost shelf is deposited the supposed leg of the NAT. HirT. Dodo, \&c.

Tables 14 to 30 contain the shells of molluscous animals (arranged according to the structure of their inhabitants); the greatest portion of which were left to the Museum by the Rev. C. M. Cracherode. Amongst these are, 1. Molluscu gasteropoda, or univalve shells; amongst these are, first, various land shells whose animals have four feelers or tentacula, such as the tomiger or grinning-snail, whose mouth is turned upwards: the polydontes or many-toothed snail; snails properly so called; achatina; bulimus; bulimulus (amongst which is the three-banded species from the West Indies, that occurs imbedded in the rock inclosing the fossil human skeleton in Room IX.); clauselia, whose animal has an internal operculum or lid: secondly; those land, freshwater, and sea-shells, with an elevated spire, whose animals have but two feelers and no lid, such as planorbis; limnæa or marsh-snail ; janthina or violet-shell, so named from the beautiful colour common to all the species; physa or fioating-snail; auricula or earsnail, and carychium: thirdly, those land, freshwater, and sea-shells, whose animals have two feelers and a lid, such as cyclostoma; paludina or marsh-shell, which produces its young alive; clithon or spiny-nerite; netitina or water-netite; nerita or sea-nerite; nautica; trochus or wheelshell ; 
Rоомviı. shell; phasianella or pheasant-shell; turritella or NaT. HIST. screw-shell; murex or woodcock-shell; buccinum or welk; harpa or harp-shell, of which there are several species; pyrula or pear-shell; pterocera or spider-shell; strombus; cassis or cask-shell; dolium or tun; mitra or mitre; voluta or volute; such as the Ethiopian, melon, and music volutes, \&c.; oliva or olive-shells; conus or cone, amongst which are the admiral and cedo-nulli cones; cyprea or cowry, such as the tortoise-shell, map and aurora cowries; ovula or egg-shell, of which there are several species; radius or shuttle-shell; bulla or bubble-shell; scaphander with its testaceous stomach (which has been described as a multivalve shell): fourthly, those shells that are covered by their animals, who have two tentacula, viz. the bullæa, with its shelly stomach, and the dolabella gigas, or gigantic dolabella: fifthly, those shells whose spire is not elevated and whose animals have two feelers and no lid, as haliotis or ear-shell, of which the red, the Cracherodean and the Iris are the most remarkable; the crepidula or slippershell; calyptræa; mitella; capulus or bonnet-limpet; scutus; emarginula or notched-limpet; fissurella or split-limpet; patella or limpet, of which the black, the tortoise, and star limpets are most remarkable.

2. Mollusca acephala or bivalve shells, viz. pholas or borer; gastrochæna; saxiclava or rockeater; solen or razor-shell; anatina; pandora; sanguinolaria; 
guinolaria; mactra; lembulus or boat-shell; cyclas Room vir. or river-cockle; tellina or telline; psammobia or NAT. HisT. sand-shell ; donax or wedge-shell; capsa; Venus, of which Dione is the most remarkable; loripes or strap-foot; lucina; cardium or cockle; isocardia or heart-shell; hippopus or horse-foot; tridacna or clamp; etheria; chama; pectunculus or pectuncle; unio or river pearl-shell; dipsas; anodonta or horse-muscle; arca or ark; margarita or pearlshell; avicula or bird-shell; malleus or hammeroyster, the black and the white species; perna ; lithodomus or stone-house; modiola; mytilus or muscle; pinna or nacre; lima; pecten or combshell; spondylus or thorny-oyster; plicatula; ostrea or oyster, the cockscomb, tree, horn of plenty, and Virginian oysters are the most remarkable; placuna or pancake-shell, of one of the species of which the Chinese sometimes make windows; anomia.

3. Mollusca brachiopoda, such as lingula or duck-shell; and terebratula, of which there are a vast number of fossil species in Room IX.

Table 31 contains specimens of limestone, coral, and wood, perforated by lythodomi, pholades, and by the teredo navalis, or ship-worm; pearl-shell of commerce, with several varieties of pearls; oysters, and other shells, showing the disease that produces pearls: pinna squamosa with its beard, out of which gloves and stockings are manufactured; 
ROOM VIII. various shells whose situation in the system has not

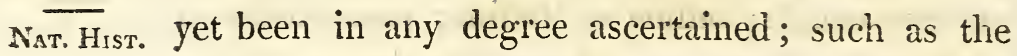
argonauts, or paper nautili: two species of nautilus, commonly 'denominated chamber nautili; waterpot shells, \&c.

Table 32 contains a collection of the shells of the class cirripedes, or barnacles, such as the diadem coronula, Lamarck's Tubicinella, or windpipe shell, several species of the newly discovered genera Pyrgoma and Creusia imbedded in coral ; Savigny's Acasta; various sorts of pentalasmis or goosebearing shell; two species of pollicipes; two species of cineras; and one of otion or eared barnacle.

Tables 33 to 36 contain crustacea, as limulus or king-crab ; rarina ; calappa or crested-crab; gecarcinus or land-crab; dromia; mithrax or spiny-crab; birgus; pagurus or hermit-crab; scyllarus or scalecrab ; palinurus or cray-fish, of which the smoothtailed, the spotted and gigantic are the most remarkable.

Table 37. In this table the old genera serpula or worm-shell and dentalium or tooth-shell are deposited.

Tables 38 to 42 contain echinodermata, such as asterias or star-fish; ophiura or snake's-tail; alecto ; gorgone-cephalus or Medusa's-head; placuna; echinus or sea-egg; \&c.

Cases 43 to 45 contain corals of various sorts, as madrepores, gorgoniæ, \&c. 


\section{NINTH ROOM.}

In this room are deposited various petrifactions, ROOM IX. together with osseous and other fossil remains. NAT. Hssr. The former are under arrangement; among the latter the more remarkable are the following:

A fossil human skeleton, imbedded in limestone, from Guadaloupe, presented by the Lords Commissioners of the Admiralty. - Skeleton of an animal of the natural order of salamanders, formerly mistaken for human (Scheuchzer's homo diluvii testis et thcoscopos). - A very perfect specimen of the skull and horns of the large Irish elk (CERvus giganteus), by far the most remarkable of the known fossil remains of ruminant animals. - A skull of the large extinct Caledonian ox.-Under jaw and other bones of the fossil Siberian elephant (ELEPHAS primigenius, $\mathrm{Bl}$.), which is the real mammoth; and of the gigantic North American animal (MASTODON Ohioticus, the mastodonte of Cuvier), which has likewise been called mammoth.--Skulls of the fossil rhinoceros ( $R$. Antiquitatis, Bl.)-Osseous remains of a huge reptile of the natural order of lizards, being a genus intermediate between the Monitor and Guana, from Maestricht in the Netherlands; and those of the Iснтнyosaurus, an animal apparently of the same natural order, but referred to the fishes by Sir E. Home, from Dorsetshire. 


\section{TENTH ROOM.}

\section{BRITISH ORYCTOGNOSTIC COLLECTION.}

ROoM X. This room contains the rudiments of a collec$\mathrm{NAT}_{\text {A }}{ }_{1 S T}$ tion of British simple mineral substances. In a series of table cases are deposited the minerals of the first seven counties of England, in alphabetical succession, from Bedfordshire to Devonshire inclusive. The names of the counties are on the upper part of these table cases, the contents of which are disposed, by longitudinal and parallel divisions, into four classes, viz. Earths, Metals, Inflammable Substances, and Salts. 'These divisions (as soon as convenient room shall be obtained) are to be continued, in the same direction, through the whole series of table cases, so that it may be ascertained at one view, if any and which of the substances belonging: to those classes, are to be met with in any given part of Great Britain.

\section{ELEVENTH ROOM}

Is appropriated to British Zoology, and at present under arrangement. 
PART II. 



\section{S Y N O P S I S}

OF THE

CONTENTS OF THE BRITISH MUSEUM. Part II.

\section{GALLERY OF ANTIQUITIES.}

\section{FIRST ROOM.}

TERRACOTTAS.

All the Articles in the following Catalogue of Antiquities, unless where it is otherwise specified, belonged to 'the Collection of the late Charles Towneley, Esq.

Over the door, which fronts the entrance into this room I. room, is a bust of Charles Towneley, Esq., to whose profound knowledge of ancient Sculpiure, and zeal in the acquisition of the finest specimens of it, the nation is indebted for the formation of a considerable part of the splendid collection of Terracottas and Marbles contained in this gallery. The bust was presented by his uncle, John Towneley, Esq. It is executed in marble by Mr. Nollekens.

No. 1. A female statue, probably one of the Muses.

No. 2. An Amphora.

No. 3. A terminal head of the bearded Bacchus.

PART II.

B

No. 4. 
RоOм I. No. 4. A bas-relief, representing a combat beAктiquitils. tween two Amazons and two Griffins.

No. 5. A bas-relief, representing the head of a Triton, on each side of which is a Cupid riding on a dolphin.

No. 6. Ditto, representing a group of Silenus and Cupid, before whom is a female Bacchante dancing and playing on the tambourin.

No. 7. Ditto, representing an engagement between one of the Arimaspi and a Griffin; on the left of the combatants is the bust of an athletic figure, armed with a battle-axe.

No. 8. Ditto, intended by the artist as a companion to No. 7, and to be joined to it in the manner in which it is here seen. The subject in both pieces is precisely the same: the bust, however, in this piece is placed on the right of the combatants, and is armed with a sword and shield.

No. 9. Repetition of No. 6.

No. 10. A bas-relief, representing a head of Medusa, on each side of which is an eagle in the act of seizing, with its talons, one of the snakes which are entwined in the locks of her hair.

No. 11. Ditto, representing a couple of chimæras lapping water out of vessels held to them by two youths who are attired in Phrygian diresses, and are each kneeling on one knee.

No. 12. Ditto, representing a female, who seems to be overwhelmed with affliction. She is seated, 
and is resting her head upon her right arm, while room I. her domestics, from the concern which is visible in Antruvirses. their countenances, appear to participate in her sorrow. This bas-relief probably represents Penelope dejected at the departure of Ulysses.

No. 13. A bas-relief, imperfect, representing a fragment of Medusa's head, on one side of which is a figure of Minerva.

No. 14. Ditto, representing the bearded Bacchus, and a female attendant on Bacchus, each of them holding a thyrsus. From the collection of Sir Hans Sloane.

No. 15. Ditto, imperfect, representing a head of Minerva and a head of Jupiter.

No. 16. Ditto, representing Minerva assisting the Argonauts to build the famous ship Argo.

No. 17. Ditto, imperfect, representing Venus on the ocean, riding upon a sea-horse.

No. 18. Ditto, representing Victory pouring out a libation to Apollo Musagetes. From the collection of Sir Hans Slaane.

No. 19. Ditto, representing a candelabrum lighted for a sacrifice. On each side stands a priestess, who with one hand supports the sacred fillets which decorate the candelabrum, and with the other hand raises a small portion of her robe, like the figure of Hope on coins of the Roman Emperors.

No. 20. Ditto, representing Machaon, after he has been wounded. He is sitting in the tent of 
Room I. Nestor, who is administering a potion to him, as Axtrqutres, described in the XIth book of the Jliad. The females, who are in attendance, are slaves.

No. 21. A bas-relief, representing Bacchus and a Faun; the former holds a thyrsus in his left hand, the latter carries a torch in his right hand, and an amphora on his left shoulder.

No. 22. Ditto, representing two Fauns, kneeling, one of them playing upon the tambourin, the other accompanying him with small musical instruments called crotala. Between them is Ampelus, the lower part of whose figure terminates in branches of the vine.

No. 23. Ditto, representing two of the Seasons, Spring and Summer.

No. 24. Ditto, representing Victory sacrificing a bull before a lighted candelabrum, which is used as an altar.

No. 25. Ditto, imperfect, representing Perseus cutting off the head of Medusa.

No. 26. Ditto, representing Victory sacrificing a bull before a small altar, which is placed upon a tripod table.

No. 27. Ditto, imperfect, representing a female Bacchante offering a basket of figs to the goddess Pudicitia. From the collection of Sir Hans Sloane.

No. 28. Ditto, representing two Fauns gathering grapes into baskets.

No. 29. Repetition of No. 21 .

No. 30. 
No. 30. A bas-relief, representing Bacchus lean- room I. ing on the shoulders of a Faun. At his feet is a Antriquitres panther holding up his mouth to receive the wine which is poured from the vase held in the right hand of Bacchus. Before this group is a female attendant on Bacchus, holding a thyrsus in her hand.

No. 31. Ditto, representing two Fauns leaning over a large open vessel of wine, as if observing the reflection of their faces on the surface of the liquor.

No. 32. Ditto, imperfect, representing a trophy, beîore which stands a captive attended by a guard, and secured by a chain fastened round his right wrist.

No. 33. Ditto, representing two Fauns gathering grapes into baskets. From the collection of Sir Hans Sloane.

No. 34. Ditto, representing Paris carrying off Helen, in a car drawn by four horses.

No. 35. 'Ditto, representing Egyptian hieroglyphics.

No. 36. Ditto, representing two persons navigating the Nile in a boat. In the fore-ground is a hippopotamus, two crocodiles, some birds, and several plants of the lotus. In the distance are buildings, on the roofs of which are seen three Ibises. The whole of this scenery is viewed through two arches supported by columns.

No. 37. Ditto, imperfect, representing a vase with two handles, on one side of which is a panther leaping up, a thyrsus, and the letter $\mathrm{A}$. 
Room 1. No. 38. A statue of the Muse Urania: both the Aкти Quitrs, hands are wanting; but, from the position of the arms, it is probable that the figure held a radius in the right hand, and a celestial globe in the left hand. It is three feet ten inches high, and is one of the largest statues which has been found of terracotta.

No. 39. An Amphora. From the collection of Sir Hans Sloane.

No. 40. A statue of a Muse, resting her left arm upon a pile of writing tablets; which are placed upon a square column. The right arm is raised towards the neck. The figure, in its present state, is three feet four inches high; the head is lost.

No. 41. An Amphora. From the collection of Sir Hans Sloane.

No. 42. A bas-relief, representing a short naked human figure, with a beard; he holds in each hand the stem of a plant. On each side of this figure is seated a quadruped, whose head is that of an elderly man, and whose tail terminates in a flower.

No. 43. Ditto, representing Cupids supporting festoons of fruit.

No. 44. Ditto, representing a Faun and a Bacchante dancing, and holding between them the infant Bacchus in a basket used for winnowing corn.

No. 45. Ditto, representing the head of Pan, on each side of which is the head of a Satyr; one of the Satyrs is crowned with branches of pine, and the other with branches of ivy.

No. 46. 
No. 46. Repetition of No. 45. ROOM I.

No. 47. A bas-relief, representing the Indian ANriquirses. Bacchus received as a guest by Icarus.

No. 48. Ditto, representing two Fauns riding on panthers. The hinder parts of the panthers terminate in vine leaves. Between the panthers is a vase with two handles.

No. 49. Ditto, representing a bull and a lion running in contrary directions. The hind legs of both animals are enveloped in foliage.

No. 50. Ditto, representing a lighted candelabrum, which is composed entirely of a plant. The flames issue from the fiower, which grows upon a long stem. On each side stands a priestess, with one hand holding up a small portion of her robe (see Nos. 19 and 54), and with the other hand holding one of the branches of the plant.

No. 51. Ditto, representing two of the Seasons, Autumn and Winter.

No. 52. Ditto, imperfect, representing the goddess Salus feeding a serpent out of a parera. The serpent is twined round the trunk of a tree, from a branch of which are suspended two cast-off skins of the serpent.

No. 53. Ditto, representing a warrior consulting the oracle of Apollo.

No. 54. Ditto, representing a lighted candelabrum, on each side of which stands a priestess, carrying a patera on her head, and holding up a 
room I. small portion of her robe with one hand. (See Nos. Antiquities. 19 and 50.)

No. 55. A bas-relief, representing Theseus slaying a Centaur.

No. 56. Repetition of No. 18.

No. 57. Repetition of No. 23.

No. 58. Repetition of No. 50.

No. 59. A bas-relief, representing two Fauns treading out the juice of grapes in a wine-press. On one side is a Faun playing upon the double pipe; and on the other side another Faun, somewhat aged in his appearance, loaded with a heavy basket of grapes.

No. 60. Ditto, representing a chariot race.

No. 61. Repetition of No. 6.

No. 62. A bas-relief, representing a mask of Bacchus, between those of a young and an old Faun.

No. 63. Repetition of No. 62.

No. 64. Repetition of No. 6 .

No. 65. A bas-relief, representing two captives in a car drawn by two horses. The captives have chains fastened round their necks and round their ancles, and the ends of the chains are held by guards walking on each side of the car.

No. 66. Ditto, representing a head of Jupiter Ammon, which rests on a flower. The ends of the fillets with which the head of Jupiter is crowned are held on each side by a Faun, who is furnished with

wings, 
wings, and whose figure terminates below in foliage, ROOM I. which curls in such a manner as to give the figure Antriqurties. the appearance of a Triton.

No. 67. A bas-relief, representing two Fauns gathering grapes into baskets.

No. 68. Ditto, representing a figure of Victory standing upon a plant, and supporting the branches of it with her hands.

No. 69. Repetition of No. 33.

No. 70. A bas-relief, representing Victory sacrificing a bull before a tripod altar.

No. 71. Ditto, imperfect, representing Theseus riding at full speed, and cutting off the head of an Amazon, whom he has caught by the hair of her head.

No. 72. Ditto, representing Venus carried through the air upon a swan.

No. 73. Ditto, representing Cupid pressing Psyche, in the form of a butterfly, to his breast.

No. 74. Ditto, representing Cupid flying, with a palm branch in one hand, and a wreath in the other.

No. 75. A terminal head of the bearded Bacchus.

No. 76. A female statue, probably of Thalia, the pastoral Muse.

No. 77. An Amphora. From the collection of Sir Hans Sloane.

No. 78. A female statue, the character unknown. The head and lower arms are modern. 
Room I. No. 79. A statue of Juno, crowned with an inAnriquities, dented diadem. Part of the arms is wanting.

Nos. 80-83. Amphoræ of various forms.

\section{SECOND ROOM.}

GREFK AND ROMAN SCULPTURES.

room Ir. No. 1. A colossal head of Minerva.

Anтrqutres. No. 2. A funeral urn, ornamented with eques. trian and pedestrian combatants.

No. 3. One of the feet, or supports, of an ancient tripod table.

No. 4. A statue of a canephora, anciently made use of as a column. It was one of the caryatides which supported the portico of a small temple dedicated to Bacchus.

No. 5. A candelabium.

No. 6. The triangular base of a candelabrum, on the sides of which three Genii hold each a part of the armour of Mars; namely, his helmet, his shield, and his sword.

No. 7. A vase, three feet high, with upright massive handles; it is of an oval form, and is ornamented all round with Bacchanalian figures.

No. 8. A statue of Venus, naked to the waist, and covered with drapery from thence downwards. It was found in the maritime baths of Claudius, at Ostia.

No. 9. A vase, two feet eight inches high, of an oval 
oval form, with wo upright double handles, which rоом II. spring from the necks of swans. The body of the Anriquities. vase in front is eniched with a group of Bacchanalians.

No.10. A fountain ornamented with ivy and olive branches. The water was conveyed through a perforation on the back part of this monument to a serpent's head, in which a leaden pipe was introduced, part of which still remains in the mouth.

No. 11. A colossal head of Hercules, dug up at the foot of Mount Vesuvius, where it had been buried by the lava of that volcano. From the colleciion of Sir William Hamilton.

No. 12. A colossal head of Hercules, in a very ancient style of Greek sculpture.

No. 13. A fragment of one of the three supports of a tripod basin, composed of the head and neck of a lion. On the forehead are the horns of a goat.

No. 14. The capital or upper division of a votive cippus.

No. 15. The key-stone of a triumphal arch, ornamented with a figure of Victory elaborately hollowed out between the two volutes. This fragment is inserted in a modern pedestal.

No. 16. A colossal head of Minerva, a specimen of very early Greek work.

No. 17. A statue of Cupid bending his bow. Purchased at the sale of the late Right Hom. Edmund Burke's marbles. 


\section{THIRD ROOM.}

GREEK AND ROMAN SCULPTURES.

Rоом IrI. No. 1. A bas-relief, representing an old Faun Antroutres. struggling with a Nymph.

No. 2. Ditto, representing a candelabrum.

No. 3. Ditto, representing a funeral column, near which is a statue of the god of Lampsacus.

No. 4. Ditto, representing Bacchus received as a guest by Icarus.

No. 5. Ditto, representing warriors consulting the oracle of Apollo.

No. 6. Ditto, in the flat early style of Grecian sculpture. It represents Castor managing a horse.

No. 7. Ditto, representing Hercules securing the Mænalian stag, which, at the command of Eurystheus, he had pursued a whole year in the forests , of Arcadia.

No. 8. Blank.

No. 9. A bas-relief, divided into three compartments. In the upper division, the infant Bacchus is represented riding on a goat; in the middle, a Triton, in attendance on Venus, is seizing a marine bull by the horns; and in the lower division is a company of hunters returning home with their spoil.

No. 10. Ditto, representing a festoon of vine branches supported by the skulls of bulls. In the centre, above the festoon, is a mask of a Faun. 
It has served as a decoration in the inside of a cir- room III. cular building.

No. 11. A bas-relief, representing the Dioscuri Antiquities. on horseback. From the collection of Sir William Hamilton.

No. 12. Ditto, representing a Bacchanalian group, consisting of three figures ; the first, a Bacchante playing on the tambourin : the second, a Faun playing on the double pipe: and the third, an intoxicated Faun holding a thyrsus.

No. 13. Ditto, representing Victory offering a libation to Apollo Musagetes. From the collection of Sir William Hamilton.

No. 14. Ditto, which has served as an ornament on the outside of a circular building. It consists of a couple of branches issuing from one stem, and curling in opposite directions.

No. 15. Ditto, representing the Centaur Nessus carrying Deianira in his arms.

No. 16. Ditto, representing a cow suckling her calf, and drinking out of a circular vessel.

No. 17. Two terminal heads, joined back to back; one of the bearded Bacchus, the other of Libera.

No. 18. A statue of the goddess Fortune.

No. 19. A terminal head of the bearded Bacchus, of very early Greek work.

No. 20. A head of Hippocrates.

No. 21. A terminal head of Mercury. Purhased at the sale of William Chinnery, Esq. 
ROom III. No. 22. A statue of Venus.

Antrutitizs. No. 23. A head of one of the Homeric heroes. It is highly animated, and is looking upwards, apparently in great agitation.

No. 24. A statue of a Faun.

No. 25. A terminal head of Homer, represented in an advanced age, with a sublime and dignified character.

No. 26. A bust of Sophocles.

No.27. A terminal head of the bearded Bacchus.

No.28. A statue of a nymph of Diana resting herself after the fatigues of the chase.

No. 29. An entire terminus of the bearded Bac. chus, six feet high.

No. 30. A terminal head of the bearded Bacchus.

No. 31. A statue of a youth holding with both hands a part of an arm which he is biting. This statue belonged to a group, originally composed of two boys who had quarrelled at the game of Tali, as appears by one of those bones called tali remaining in the hand of the figure which is lost.

No. 32. A terminal head of Pericles, helmeted, and inscribed with his name.

No. 33. A statue of a Faun, inscribed with the name of the artist.

No. 34. A terminal head of Epicurus.

No. 35. A terminal statue of Pan playing upon a pipe.

No. 36. A Greek inscription upon a circular shield, 
shield, containing the names of the Ephebi of Roomin. Athens under Alcamenes, when he held the office ANrrqutres. of Cosmetes.

No. 37. A terminal statue, supposed to be that of Venus Architis.

No. 38. A circular votive patera.

No. 39. An unknown bronze head, supposed to be that of Pindar. Presented, in 1760, by the Earl of Exeter.

No. 40. A circular votive patera, with a head of Pan in very high relief.

No.41. A Greek sepulchral monument. The basrelief in front represents a trophy, on one side of which stands a warrior, and on the other a female figure feeding a serpent, that is twined round the trunk of a tree on which the trophy is erected. On the right of these figures is the fore part of a horse. An inscription on the top of this monument contains a list of names, probably of those whe fell in some engagement. Presented by the Right Hon. Sir. Joseph Banks and the Hon. A. C. Fraser.

No. 42. A terminal head of Periander.

No. 43. A repetition of No. 33 .

No. 44. An unknown terminal head, probably of a Greek poet.

No. 45. A statue of Actæon attacked by his dogs.

No. 46. A terminal head of the young Hercules. It is crowned with the leaves of the poplar. 
FOURTH ROOM.
GREEK AND ROMAN SCULPTURES.
1. A bust of Trajan, with the breast naked.

FOURTH ROOM.
GREEK AND ROMAN SCULPTURES.
1. A bust of Trajan, with the breast naked.

GOURTH AND ROMAN SCULPTURES.
RoOM IV. No. 1. A bust of Trajan, with the breast naked. Antriquities. No. 2. A bronze statue of Hercules carrying away the apples from the garden of the Hesperides.

No. 3. One of the feet, or supports, of an ancient tripod table.

No. 4. A head of Apollo, of very early Greek work.

No. 5. A statue of Thalia, found at Ostia, in the maritime baths of the emperor Claudius.

No. 6. A head supposed to be that of Arminius.

No. 7. A bronze statue of Apollo.

No. 8. One of the feet or supports of an ancient tripod table, executed in porphyry. It represents the head and leg of a panther.

No. 9. A colossal head of Marcus Aurelius, who is represented in the character of one of the Fratres Arvales.

No. 10. A colossal bust of Lucius Verus covered with the imperial paludamentum.

No. 11. A group of Bacchus and Ampelus.

No. 12. A head of the young Hercules.

No. 13. A head supposed to be that of Dione.

No. 14. A statue of Diana.

No. 15. A bust of Hadrian, with the breast naked. 


\section{FIFTH ROOM.}

ROMAN SEPULCHRAL ANTIQUITIES.

No. 1. A sepulchral urn, with a bas-relief in RCON V. front; it appears never to have been used, as it is Antreviries. solid, and without any inscription. Presented by A. Mackinnon, Esq.

No. 2. Ditto with an inscription to Atimetus. Presented by A. Mackinnon, Esq.

No. 3. A funeral inscription to M. Nrvius Proculus. Presented by Thomas Hollis, Esq.

No. 4. A sepulchral urn, with an inscription to . Vernasia Cyclas.

No. 5. Ditto with an inscription to L. Lepidius Epaphras. Presented by A. Mackinnon, Esq.

No. 6. Two earthen ollæ, placed in the manner of those which contained the ashes of the slaves and the inferior order of the Roman people. The monumental inscription, in front of them, records the names of Anniolena Maxima and Servilia Irene.

No. 7. A sepulchral urn, with an inscription to Pompeius Justinianus.

No. 8. Ditto, with an inscription to T. Titulenus Isauricus.

No. 9. Blank.

No. 10. A sepulchral urn, with an inscription to Fl. Alius Victor.

No.11. Ditto, with an inscription to Silia Attica. PART II. 
ROOM V.

No. 12. A sepulchral vase, found in a tomb near Antiquities. Naples.

No. 13. A sarcophagus, on the front of which is represented the lamentation of a family over a corpse.

No. 14. A sepulchral urn, with an inscription to Serullia Zosimenes.

No. 15. Ditto, with an inscription to P. Licinius Successus.

No. 16. Blank.

No. 17. A sepulchral urn, with an inscription to Cossutia Prima.

No. 18. Ditto, with an inscription to Ti. Claudius Lupercus. Presented by A. Mackinnon, Esq.

No. 19. Two earthen ollæ, similar to those described at No.6. The monumental inscription, placed in front of them, records the names of $\mathrm{P}$. Stenius Rufus and Plosurnia Salvilla.

No. 20. A funeral inscription to Eutychia. Presented by Thomas Hollis, Esq.

No. 21. An Etruscan cinerary urn in baked clay. The bas-relief in front represents the hero Echetles fighting with a ploughshare for the Greeks at the battle of Marathon. Upon the cover is a recumbent female figure.

No. 22. A sepulchral urn, with an inscription to Claudia Fortunata. From the collection of Sir Hans Sloane.

No. 23. A funeral inscription to Lucretia. Presented by Thomas Hollis, Esq.

No. 24. 
No. 24. An Etruscan cinerary urn in baked clay. room v. The story of Echetles is represented in front (see Antrquiries. No. 21.), and on the cover is a recumbent female figure. The figures on this monument were originally painted. On the upper part of the urn is an Etruscan inscription in red letters. From the collection of Sir William Hamilton.

No. 25. A sepulchral urn, with an inscription to T. Sex. Agatha.

No. 26. A sepulchral vase, in alabaster, with an inscription to Flavia Valentina.

No. 27. A sepulchral urn, with an inscription to Junia Pieris.

No.28. An earthen olla, similar to those described at No.6. The monumental inscription placed in front of it, records the name of Opilia Faustilla.

No. 29. A sepulchral urn, with an inscription to Cœlia Asteris. From the collection of Sir IVilliam Hamilton.

No.30. Ditto, with an inscription to P. Octanius Secundus.

No. 31. A fragment of a testamentary inscription, cut from a sepulchral cippus.

No. 32. A sepulchral urn, with an inscription to Pompeius Locusto, Attilia Clodia, and Pompeius. From the collection of Sir William Hamilton.

No. 33. Ditto, with an inscription to C. Magius Pal. Heraclides.

No.34. An Etruscan cinerary urn in baked clay. 
Room $\mathrm{v}$. The bas-relief in front represents the single combat Antrivities. between the two brothers, Eteocles and Polynices. The two female figures, who are standing near the combatants, are Furies. An Etruscan inscription is painted in red letters on the upper part of this urn; on the cover is a recumben $\mathrm{t}$ female figure. From the collection of Sir. IVilliam Hamilion.

No.34*. A sepulchral vase, in yellow alabaster.

No. 35. A sarcophagus, on the front of which various figures of Cupid and Psyche are repre. sented.

No. 36. A sepulchral urn, with an inscription to D. Albiccus Licinus.

No. 37. Ditto, with an inscription to Flavia Eunya.

No. $37 \%$. A sepulchral vase, in yellow alabaster.

No. 38. A monumental inscription to Dasumia Soteris.

No. 39. A sepulchral vase, in alabaster. From the collection of Sir. IVilliam Hamilton.

No. 40 . A sepulchral urn, with an inscription to Isochryses.

No.41. An earthen olla, similar to those described at No. 6. The monumental inseription, placed in front of it, records the name of Apuleia Tychen.

No.42. A funeral inscription to Flavia Provincia.

No. 43. A sepulchral urn, with an inscription to Pilia Philtata. From the collection of Sir IV Illiam Hamilton. 
No. 44. A funeral inscription to Isidorus. Pre- room v. sénted by Thomas Hollis, Esq.

No. 45. A mosaic pavement, discovered in digging the foundation for the new buildings at the Bank of England. Presented by the Directors of the Bank.

\section{SIXTH ROOM.}

GREEK AND ROMAN SCULPTURES.

No. 1. A medallion, representing in profile the room vi: bust of an unknown Greek philosopher.

No. 2. Part of the front of a sarcophagus, representing Achilles among the daughters of Lycomedes.

No. 3. A bas-relief, cut from the end of a sarcophagus; it represents two Fauns punishing a Satyr.

No. 4. Part of the front of a large sarcophagus, representing a marriage.

No. 5. The front of a sarcophagus, representing the nine Muses with their respective attributes.

No. 6. A bas-relief, cut from the end of the same sarcophagus as No. 3. It represents two Cupids and a Faun carrying an intoxicated Satyr.

No. 7. Part of a sarcophagus, representing a carpentum, or funeral car, drawn by four horses.

No.8. A medallion, representing in profile the bust of an unknown Greek philoscpher. It is similar to No. 1, but of a later time and inferior sculpture. 
Rоoм VI. No. 9. The front of a sarcophagus, representing Antrqurtizs. captive Amazons with their shields and battle-axes.

No. 10. A fragment of a sarcophagus, representing Bacchus with a thyrsus in his left hand, and with his right arm thrown over the shoulders of a Faun.

No. 11. A fragment of a magnificent sarcophagus, representing an elderly man with a manuscript. roll in his hand, which he is reading. Before hims standis a Muse holding a mask.

No. 12. The front of a sarcophagus, representing a Bacchanalian procession.

No. 13. Heads of Paris and Helen, in alto-relievo.

No. 14. The front of a sarcophagus, representing: Genii supporting various pieces of armour. On a shield, in the centre, is an inscription to Sallustius Iasius.

No. 15. A head of Jupiter.

No. 16. A terminal statue of a youth, who is represented with the attributes of Mercury.

No. 17. A votive aitar, sacred to Apollo.

No. 18. A head of Apollo Musagetes, resembling, in the disposition of the hair and in the character of the face, the head of a Muse.

No. 19. A Greek inscription, being a decree of the people of Athens, and of the Piræus, in honour of Callidamas. Presented by the Dilettanti Society.

No. 20. A votive statue of Diana triformis, with a dedicatory inscription round the plinth.

No. 21. 
No. 21. An altar of Roman work, ornamented with Egyptian figures.

No. 22. A bust, inscribed to the memory of $\mathrm{Cl}$. Olympias, by Epithymetus, her freed-man. Purchased at the sale of the late Right Hon. Edmund Burke's Marbles.

No. 23. A funeral monument of Xanthippus, who is represented sitting in a chair, and holding a human foot in his right hand.

No. 24. A statue of a Satyr.

No. 25. An altar, on which various Egyptian figures are represented. It is of Roman work.

No. 26. A head of an Amazon, in the early style of Greek sculpture.

No. 27. A Greek sepulchral monument, with a bas-relief, and an inscription to Mousis who was a native of Miletus, and daughter of Argæus. Presented by Thomas Hollis, Esq.

No. 28. A figure of Victory sacrificing a bull.

No. 29. A bust of Hadrian with the imperial paludamentum.

No. 30. A foot covered with a sandal.

No. 31. A statue of Diana Lucifera, of which the head and arms are lost. It was found at Woodchester, in the county of Gloucester. Presented sy Samuel Lysons, Esq.

No. 32. A small statue of Jupiter sitting. He is represented in his two-fold capacity, as king of the upper and lower regions.

No. 33 . 
Room VI. No. 33. A bas-relief, representing Priam in the Antroutries act of supplicating Achilles to deliver to him the body of his son Hector.

No. 33*. A Greek inscription, anciently placed under a statue of Jupiter Urius, which stood within a temple erected to that deity at the mouth of the Pontus. Presented by Miss Mead.

No. 34. A bust of Severus with the imperial paludamentum.

No. 35. A bronze statue of a Roman Emperor, probably of Nero when he was young. The figure is represented in armour, which is most beautifully inlaid. It was found near Barking-Hall, in Suffolk, on the estate of the Earl of Ashburnham. Presented, in 1813, by the Earl of Ashburnham.

No. 36. A foot covered with a sandal. This and No. 30 belonged to the same statue.

Nos. $34 *, 35 *, 36 *$. Three tiles, in terracotia, brought from Athens. The fronts are ornamented with a border of the honeysuckle pattern, and in the centre of each is the head of a lion, for carrying of the water. Puichased in 1815.

No.37. A sarcophagus, in the centre of which is the portrait of an elderly man, placed in the insile of a shield, which is supported by two Genii.

No. 38. A colossal foot of Apollo. Presenie? by Sir William Hamilton.

No. 39. A figure of Victory sacrificing a bull. 
No. 40. A head of Faustina, the wife of Marcus room vi. Aurelius.

No. 41. A triangular base of a small candelabrum.

No. 42. A sepulchral cippus, with an inscription to Viria Primitiva.

No. 43. A swan, in red marble.

No. 44. A votive altar, dedicated to Silvanus.

No. 45. A head of Tiberius. Purchased at the sale of the late Right Hon. Edmund Burke's Marbles.

No. 46. A Greek sepulchral monument, with a bas-relief, and an inscription to Isias, who was a native of Laodicea, and daughter of Metrodorus. Brought from Smyrna. Presented by Matthew Duane, Esq. and Thomas Tymohiti, Esq.

No. 47. An eagle.

No. 48. A triangular base of a candelabrum, the sides of which are ornamented with the attributes of Apollo; namely, a griffin, a raven, and a tripod.

No. 49. A head of Plautilla.

No. 50. A votive altar, dedicated to Diana.

No.51. A sepulchral cippus, which appears never to have been used, a blank space being left for the inscription.

No. 52. A statue of Libera, holding a thyrsus over her right shoulder and a bunch of grapes in her left hand; at her feet is a panther.

No. 53. A head of Atys. 
Room vi. No.54. A head of an unknown female, the hair Antrourres. elegantly bound with broad fillets.

No. 55. A statue of Ceres, crowned in the man. ner of Isis.

No. 56. A head of Nero.

No. 57. A votive statue of a fisherman, who is carrying a round leathern bucket suspended from his left arm. The head is covered with a mariner's bonnet, and a dolphin serves as a support to the figure.

No. 58. A sepulchral cippus, without an inscription. On the front, beneath a festoon which is composed of fruits and foliage, and is suspended from the skulls of bulls, are two birds perched on the edge of a vase, out of which they are drinking.

No. 59. A Greek sepulchral urn, solid, and with a bas-relief in front; it is inscribed with the names of Pytharatus and Herophilus. From the collection of Sir Hans Sloane.

No. 60. A Grecian altar. Presented by Sir William Hamilton.

No. 61. A head of Augustus. Purchased at the sale of the late Right Hon. Edmund Burke's Marbles.

No. 62. A Greek funeral monument of Democles, the son of Democles, with a bas-relief, and an inscription in eight elegiac verses. It was brought from Smyrna. Presented by Matthew Duane, Esq. and Thomas Tyrwhitt, Esq.

No. 63. 
No. 63. A statue of Bacchus, represented as a Room vi. boy about five years old. The head is crowned with Antrumires. a wreath of ivy, and the body is partly covered with the skin of a goat.

No. 64. The front of a votive altar, with an inscription for the safe return of Septimius Severus and his family from some expedition. The parts in the inscription which are erased contained the name of Geta, which by a severe edict of Caracalla was ordered to be erased from every inscription throughout the Roman empire.

No. 65. A bust of Caracalla: the head only is antique.

No. 66. A votive statue of a fisherman, holding a basket of fish in his left hand.

No. 67. A votive altar, sacred to Bacchus. On the front, Silenus is represented riding upon a panther.

No. 68. A group of two dogs, one of which is biting the ear of the other in play.

No. 69. An unknown bust, dressed in the Roman toga.

No. 70. A head of a female child. The hair is divided into plaits, which are twisted into a knot on the back part of the head. Some of the red paint, with which the hair was originally coloured, is still visible.

No. 71. A fragment of a colossal foot.

No. 72. A small statue of a Muse, sitting on a rock, and holding a lyre in her left hand.

No. 73 . 
Room vi. No. 73. A small statue of Cupid bending his Antreutties. bow.

No. 73*. A bas-relief, representing a female Bacchante dressed in thin floating drapery, through which the beautiful forms of her body are perfectly apparent. With one hand, which is held somewhat above her head, she holds a knife, and at the same time secures a portion of her robe which is blown behind her; with the other hand, which is held downward, she carries the hind quarters of a kid. This piece of sculpture was anciently one of the ornamental figures on the triangular base of a candelabrum.

No. 74. A small statue of Hercules, sitting on a rock.

No. 75. A bust of Gordianus Africanus the elder, dressed in the Roman toga.

No. 76. A colossal hand.

No. 77. A head of a child.

No. 78. The front of the cover of a magnificent sarcophagus. It represents a group of cattle, on one side of which is an old Faun, and on the other a young Faun, both recumbent.

No. 79. A fragment of a mask of Bacchus.From the collection of Sir. William Hamilton.

No. 80. A votive foot, with a sandal. Round the foot a serpent is twined, with its head resting on the summit, which terminates a little above the ancle.

No. 81. An earthen vase, which has two handles 
at the neck, and terminates in a point at the bottom, ROOM VI. like an amphora. It was found in the baths of ANTrquities. Titus, with above seventy others of the same sort; all of them contained the fine African sand, with which, when mixed with oil, the Athletæ rubbed their bodies before they exercised.

No. 82. A votive foot, covered with a sandal, and having a serpent twined round it, in the same manner as is described at No. 80 .

No. 83. A mask of Bacchus.

Nos. 82*, 83*. Two tiles of baked clay, from Athens. The fronts of them are ornamented with paintings.

No. 84. A sphinx, which anciently formed part of the base of a superb candelabrum.

No. S4*. An unknown head. Purchased in 1818.

No. 85. A head of Sabina.

No. 86. A small figure of a recumbent Satyr.

No. 87. A sepulchral cippus, without an inscription. It is richly ornamented on the four sides with festoons of fruit.

No. 83. An Egyptian tumbler, practising his art on the back of a tame crocodile.

No. 89. A sepulchral cippus, with an inscription to M. Colius Superstes.

No. 90. An unknown bust of a middle-aged man. The hair of the head and beard is short and bushy; the left shoulder is covered with part of the anlainys ; 
Rоoм VI. chlamys ; the right shoulder and breast are uncoAntiquitias. vered. On the plinth is an inscription, signifying that L. Emilius Fortunatus dedicates the bust to his friend.

No. 91. A Greek sepulchral monument, with a bas-relief, and an inscription to Exacestes and Metra his wife.

No. 92. A trophy, found on the plains of Marathon. Presented by John Walker, Esq.

No. 93. A sepulchral cippus, with an inscription to T. Clandius Epictetus.

No. 94. A head of Domitia.

No. 95. A torso of Hercules.

No. 96. A monumental inscription, cut from the front of a sepulchral cippus. It records the name of Claudia Tychen.

No. 96*. A head of Demosthenes. Purchased in 1818 .

No. 97. A statue 3 feet 10 inches high, ending from the waist downwards in a terminus. In the right hand is a bunch of grapes, at which a bird, held under the left arm, is pecking.

No. 98. A votive altar, with a dedicatory inscription to Bona Dea Annianensis.

No. 99. A head of Jupiter Serapis. The paint with which the face was anciently coloured is still discernible.

Nos. 100, 101. Two bas-reliefs from Persepolis. Presented, in 1817, by the Earl of Aberdeen. 


\section{SEVENTH ROOM.}

\section{ROMAN ANTIQUITIES.}

No. 1. An unknown statue: it is clothed in the Room vir. Roman toga.

No. 2. A bust of a sleeping child, in alto-relievo. Antiquities.

No. 3. A fragment of a frieze, representing two Cupids running a race, in cars drawn by dogs; they appear to have just started from the carceres of a circus.

No. 4. A pig of lead, with the name of the Emperor Domitian inscribed upon it. It weighs 154 pounds. It was discovered, in the year 1731, under ground, on Hayshaw Moor, in the manor of Dacre, in the West Riding of Yorkshire. Bequeathed by Sir .John Ingilby, Bart.

No. 5. Ditto, inscribed with the name of $L$. Aruconius Verecundus. It weighs 81 pounds. It was found near Matlock Bank, in Derbyshire. Presented by Adam Wolley, Esq.

No. 6. A large sepulchral cippus, with an inscription to M. Clodius Herma, Annius Felix, and Tyrannus.

No. 7. A tragic mask.

No. 8. The front of a sarcophagus, with a Greek inscription to M. Sempronius Neicocrates.

No. 9. A pig of lead, with the name of the Emperor Hadrian inscribed upon it. It weighs 191 pounds. 
ROom vir. pounds. It was found, in the year 1796 or 1797 , Antrqutries. in a farm called Snailbeach, in the parish of Westbury, 10 miles S. W. of Salop. Presented by John Lloyd, Esq.

No. 10. A pig of lead, also inscribed with the name of the Emperor Hadrian. Its weight is 125 pounds. It was found in Cromford Moor, in Derbyshire. Presented by Peter Nightingale, Esq.

No. 11. A large sepulchral cippus, with an inscription to Agria Agatha.

No. 12. A statue of Septimius Severus, clothed in the imperial paludamentum.

\section{EIGHTH ROOM.}

EGYPTIAN ANTIQUITIES.

Roomvir. No. 1. The cofinn of an Egyptian mummy, sent Antrquities. to England by Edward Wortley Montagu, Esq. and presented to the Museum by His Majesty. In the left hand corner of this case is a conical vessel of baked clay, containing an embalmed Ibis.

No. 2. Two Egyptian mummies. That on the left hand, which has been elaborately and beautifully ornamented with coloured glass beads, some of which still remain, was taken out of the coffin above mentioned. That on the right hand, the face of which is gilt, and the other parts of the body ornamented with paintings, was taken out of the coffin which will be described in the next number. 
In the lower part of this case is a small Egyptian room virr. coffin of a square form: it contains the mummy Axtrqurries. of a child. The lid and sides of this enffin are covered with paintings.

No. 3. The coffin of an Egyptian mummy, found in one of the catacombs at Sakkara, about four leagues from Cairo, and sent to England, in the year 1722 , by Col. William Lethieullier, who bequeathed it to the Museum.

No. 4. A collection of vases, usually known by the name of Canopuses. The lids are severally ornamented, with a head of Isis, Osiris, a hawk, a wolf, or a baboon.

No. 5. A collection of Egyptian idols, in bronze; among them are three sistrums.

No. 6. A collection of Egyptian idols, in wood; Egyptian idols of Roman work, apparently of the time of Hadrian;-idols and amulets of the Basilidians, who spread their mysterious doctrines, and practised their magical arts, in Egypt, from the time of Hadrian to the fifth century;-Egyptian scarabæi, or beetles, found in mummies;-small idols in basalt.

No. 7. A collection of Egyptian idols in porcelain.

No. 8. Various fragments of small statues in basalt, marble, and alabaster. Among them are a few perfect figures, namely two of Harpocrates, one of a baboon, and another of an Apis. At the

PART II.

D

bottom 
ROom VIIr. bottom of this case is a bas-relief, and some large Antruutres. idols in wood.

Opposite the entrance to this Room, against the wall, is a frame containing the bones of an embalmed ibis, which was presented by the Right Hon. Sir Joseph Banks. Underneath is a manuscript taken from a mummy: it is written on papyrus, in the enchorial characters of Egypt, and was presented by $W m$. Hamilton, Esq. as were also the fragments of another manuscript on papyrus, which are placed near it. On the right hand of the door is a frame, containing an Egyptian painting, taken from the breast of a mummy.

\section{NINTH ROOM.}

\section{EGYPTIAN SCULPTURES.}

room Ix. The articles contained in this Room are princiAntrourtiss. pally those which were collected by the French in different parts of Egypt, and came into the possession of the English army, in consequence of the capitulation of Alexandria, in the month of September, 1801. They were brought to England in February, 1802, under the care of General Thmer, and were sent, by order of His Majesty, to the British Museum. Such articles as did not form part of the above-mentioned collection are particularly specified. 


\section{5}

No. 1. A large Egyptian sarcophagus, of breccia, Room Ix. brought from the mosque of Saint Athanasius, at Antroutriss. Alexandria. It is covered with hieroglyphics both within and without.

No. 2. Another large Egyptian sarcophagus, of black granite, also covered with hieroglyphics, inside and outside. This sarcophagus, which was brought from Grand Cairo, was used by the Turks as a cistern, which they called "The Lover's Fountain."

No. 3. A small mutilated figure of Isis sitting on the ground, and resting her arms upon her knees. An ear of corn is held in the left hand, and in front of the figure is the head of Orus. Presented, in 1767, by the Earl of Bute.

No. 4. A fragment of an Egyptian Deity, similar to No. 10.

No. 5. A sphinx, represented, according to the custom of the Egyptians, without wings. Presented, in 1767, by the Earl of Bute.

No. 6. A capital of an Egyptian column. Presented, in 1805, by Earl Spencer.

No. 7. An Egyptian monument in which are sunk two square tablets, one of which is left blank, and in the other are represented two female figures standing side by side. These tablets are surrounded. by hieroglyphics. From the collection of Sir Hans Sloane.
D 2
No. 8. 
ROOM Ix: No. 8. A figure of Isis, the size of life. She is Aлттиттев. represented sitting on the ground, resting her arms upon her knees, and holding an ear of corn in her right hand. In the front is the head of Orus.

No. 9. A mutilated Egyptian figure, kneeling on a square plinth, round which is a border of hieroglyphics.

No. 10. A large statue of an Egyptian Deity sitting in a kind of chair, and resting its arms upon the thighs. In the left hand is held the sacred instrument called the Tau. The head of this Deity is that of a lion, the rest of the figure is human. The disc and the erect serpent's head have been knocked off from the upper part of this figure, but in the next statue they are nearly entire.

No. 11. Similar to No. 10.

No. 12. A fragment of a porphyry column.

No. 13. An Egyptian coffin, slightly resembling in its form the human figure. It has a single border of hieroglyphics round the outside.

No. 14. A fragment of a porphyry column.

No. 15. Part of the frieze of an Egyptian temple. It is covered with hieroglyphics on both sides. The upper part of the front of this frieze consisted of a row of birds, the legs of which are all that now remain. Presented by His Majesty.

No. 16. An Egyptian obelisk.

No. 17. Part of the frieze of an Egyptian temple. 
ple. It is covered with hieroglyphics on both sides. RoOM IX. The upper part of the front of this frieze consists Anriquiries. of a row of Serpents. Presented by His Majesty.

No 18. A small Egyptian figure, with a beard, a short apron, and a terrific aspect. He is standing upright, but holding his arms downwards, a little apart from the body. The ornament upon the head is peculiar to the representation of this figure. From the collection of Charles Towneley, Esq.

No. 19. A head of an Egyptian sphinx. From the collection of Charles Towneley, Esq.

No. 20. A small Egyptian figure kneeling upon a square plinth, and supporting with his hands a kind of altar, in front of which, within a sunk tablet, is a figure of Osiris. Presented by Matthew Duane, Esq.

Nos. 21, 22. Fragments of an Egyptian Deity. similar to No. 10.

No. 23. The Rosetta stone, containing three inscriptions of the same import, one in hieroglyphics, another in the ancient vernacular language of Egypt, and another in the Greek language. These inscriptions record the'services which Ptolemy the Vth had rendered his country, and were engraved by order of the High Priests, when they were assem. bled at Memphis, for the purpose of investing him with the royal prerogative. This stone was found near Rosetta.

No. 24. A colossal head of Jupiter Ammon, 
Room Ix. Who was represented by the Egyptians with the head Antiquities. of a ram.

No. 25. An Egyptian obelisk.

No.26. A colossal fist, of very considerable magnitude.

No. 27. Ditto, of a much smaller size than the preceding one. Presented, in 1805, by Earl Spencer.

No. 28. A fragment, covered with hieroglyphics. Presented, in 1805, by Earl Spencer.

No. 29. A fragment of a large sarcophagus, similar in its structure to Nos. 1 and 2.

No. 30. A fragment, which was found at the foot of Pompey's Pillar, and is partly covered with hieroglyphics.

No. 31. An Egyptian bas-relief, consisting of a double range of figures. The upper range is imperfect, half of the figures having been broken off. The lower range represents some priests armed with knives, with which they are sacrificing bulls. It was found near Sakkara, four leagues from Grand Cairo. Presented, in 1767, by the Earl of Bute.

No. 32. A fragment of a porphyry column.

Nos. 33, 34. Statues of Egyptian Deities, similar to No. 10.

No. 35. A mutilated kneeling figure supporting with both its hands an altar, on which a scarabæus is placed. Presented, in 1805, by Earl Spencer.

No. 35*. The lower part of an Egyptian figure kneeling on a square plinth, round which is a border 
of hieroglyphies. Presented by His Royal Frigh- Room xx. ness the Duke of York.

No. 36. A votive column, on which is an inscription in Greek to the great Grod Serapis at Canopus. It was brought from Aboukir. Presented by $D r$. Bancroft, Jun.

No. 37. A colossal hawk. Presented by $M r . T$. Philipe.

No. 38. A fragment of an Egyptian Deity, similar to No. 10.

No. 39. A small mutilated Egyptian figure, kneeling on a square plinth.

The fragments of Mosaic pavement (placed for the present in this Room) were found at Withington in Gloucestershire. They were presented by Henry Brooke, Esq.

\section{TENTH ROOM.}

\section{GREEK AND ROMAN SCULPTURES.}

No. 1. A head of Juno, crowned with a broad room x. indented diadem.

No. 2. An upright narrow piece of marble, ornamented with branches of the olive and the vine.

No. 3. A head, apparently of a trumpeter.

No. 4. An unknown female head. The sockets of the eyes are hollow, and have been originally filled with coloured stones, or some other material.

No. 5. A torso of a small statue of Venus.

No. 6. 
Rоom x. No. 6. An unknown female head, with a broad ANTrQUITIEs. fillet across the forehead.

No. 7. A head of a goat.

No. 8. Cupid sleeping upon a lion's skin.

No.9. An epitaph on a dog. From the collection of Sir Hans Sloane.

No. 10. An unknown head.

No. 11. A head of Apollo.

No. 12. A head of a lion, being a fragment of a large sarcophagus.

No. 13. An oblong square basin of granite, similar to such as were used in the temples, to contain the water necessary for the purification of those who sought to gain admittance to the sacrifices.

No. 14. A mask cut from the cover of a large sarcophagus. From the collection of Sir IVilliam Hamilton.

No. 15. A terminal head of Libera.

No. 16. A head of a female Bacchante.

No. 17. A case containing a collection of antique bronzes.

No. 18. A head of a laughing Faun.

No. 19. Small terminal heads of Bacchus and Libera, joined back to back.

No. 20. A small terminal head of Libera. From the collection of Sir William Hamilton.

No. 21. Ditto, in yellow marble.

No. 22. Ditto, in red marble. 
No. 23. A small terminal head of Libera, in room $x$. reddish yellow marble, with a necklace composed of ANTIQUITIEs. ivy leaves.

No. 24. Ditto, in white marble, with the breast covered with drapery. From the collection of Sir William Hamilton.

No. 25. A small terminal head of the bearded Bacchus. From the collection of Sir William HIamilton.

No. 26. A small female head, the hair of which is formed of a distinct piece of marble, and is fitted to the head in the manner of a wig.

No. 27. A small head of a young man, covered with a helmet, which is ornamented with the horns of a ram. From the collection of Sir IVilliam Hamilton.

No. 28. A small mask of Silenus. From the collection of Sir William Hamilton.

No. 29. A small cylindrical piece of marble, which appears to have been part of the stem of a candelabrum. It is ornamented with four griffins, and two candelabra.

No. 30. A fragment of a bas-relief, representing the head of an elderly man. It has the beard on the chin and upper lip, and the hair of the head is short and curly. From the collection of Sir William Hamilton.

No. 31. A bas-relief, representing a comic and a tragic mask.

No. 32. 
room x. No. 32. A fragment of a bas-relief, representing Axtrqutres. a head of Antinous. From the collection of Sir William Hamilton.

No. 33. A votive barrel sacred to Bacchus.

No. 34. A small terminal head of the bearded Bacchus, in yellow marble. From the collection of Sir Hans Sloane.

No. 35. A votive horn, in marble, two feet long.

No. 36. A head of Adonis, covered with the pyramidal hood. The lower part of the face and neck is covered with drapery.

No. 37. A head of Jupiter Serapis in green basalt.

No. 38. A small statue of a Muse, sitting on a rock, and playing on a lyre.

No. 39. A head of Jupiter Serapis. From the collection of Sir William Hamilton.

No. 40. A piece of mosaic pavement, found at Woodchester, in the county of Gloucester. Presented by Samuel Lysons, Esq.

No. 41. A statue of a Discobolus, who is represented at that precise moment of time which immediately precedes the delivery of the discus. It is an ancient copy in marble, from the celebrated bronze statue executed by Myro.

No. 42. A small bust of Antoninus Pius; the head only is antique.

No. 43. A small scenic figure, sitting on a square plinth. The face is covered with a comic mask. 
No. 44. A bust of a child, with the breast room $\mathrm{x}$. naked.

No. 45. A bas-relief, representing the arms of the Dacians and Sarmatians.

No. 46. A bust of an unknown female, represented in the character of Isis. It is gracefully terminated by the flower of the Nymphæa Lotus, on which it appears to rest.

No. 47. A head of a Muse, crowned with a wreath of laurel.

No. 48. A case containing a collection of antique bronzes.

No. 49. A head of one of the Dioscuri.

No. 50. A fragment of a small head of Hercules, covered with the skin of a lion. Presented by Thomas Hollis, Esq.

No.51. A funeral mask, which was used to cover the face of a female corpse. From the collection of Sir IV illiam Hamilton.

No. 52. A small head of Hercules. Presented by Thomas Hollis, Esq.

No. 53. A small unknown bust, with a military garment. The head is of yellow marble. Presented by Thomas Hollis, Esq.

No. 54. A small head of Hercules very much injured by the decomposition of the marble. From the collection of Sir IVilliam Hamilton.

No. 55. The capital of a small column of the Ionic order. From the collection of Sir William Hamilton.

No. 56. 


\section{4}

Room x. No. 56. A small unknown head. From the colAxtreurtrs. lection of Sir William Hamilton.

No. 57. A small head of Vulcan, covered with a cap. From the collection of Sir William Hamilton.

No. 58. A votive mask of a bearded Faun. Presented by Thomas Holiis, Esq.

No. 59. A small unknown female head, the hair of which is tied in a knot behind. From the collection of Sir William Hamilton.

No. 60. A small head of Juno. Presented by Thomas Hollis, Esq.

No. 61. A group representing Venus and two Cupids.

No. 62. One of the handles of a vase. From the collection of Sir William Hamilton.

No. 63. A fragment of a bas-relief, representing part of a female figure. From the collection of Sir William Hamilton,

No. 64. A bas-relief, representing a mask of a Faun.

No. 65. A left foot, covered with a sandal.

No. 66. The right foot of a child.

No. 67. A hand of a female, holding a lock of hair. This fragment probably belonged to a statue of Venus, who was represented in the act of wringing the water from her hair. From the collection of Sir IVilliam Hamilton.

No. 68. The right hand of a female holding a pipe.

No. 69. 
No. 69. A lion's foot, which probably has formed Rоoм x. part of a tripod table.

No. 70. The left hand and part of the arm of a female, probably Psyche, holding a butterfly.

No. 71. A lion's foot, which has been applied to the same purpose as No. 69.

No. 72. The left hand of a female, stretched out upon a fragment of something unknown.

No. 73. The right hand of a youth, holding, apparently, a fragment of a bow. This is probably part of a statue of Cupid bending his bow.

No. 74. The right hand of a child, holding the head of a ram.

No. 75. A left foot, covered apparently with linen, round which bandages are fastened.

No. 76. A large votive patera, with a bas-relief on each side, one representing Silenus, and the other a Satyr. From the collection of Sir IVilliain Hamilton.

No. 77. A small fragment of a figure holding a bird.

No. 78. The left hand of a child, holding a fragment.

No. 79. A torso of a male figure, the arms of which appear to have been raised above the head.

No. 80. A small mutilated figure. The right breast is naked, the other parts are entirely covered 
Room $\mathrm{x}$. with drapery. It has a necklace, from which a Antruviries. scarabæus is suspended.

No. 81. A head of an eagle, which appears to have served as the hilt of a sword. From the collection of Sir Milliam Hamilton.

No. 82. A votive patera, with a bas-relief on each side, one representing a mask of the bearded Bacchus, and the other a panther. From the collection of Sir IVilliam Hamilton.

No. 83. A fragment of a serpent.

No. 84. A head of Apollo.

No. 85. A head of Cybele.

No. 86. A head of a lion, which was a part of the same sarcophagus from which No. 12 was taken.

No. 87. A cistern of green basalt, anciently used as a bath. On the sides are carved two rings in imitation of handles, in the centre of which is a leaf of ivy.

No. 88. A head of Minerva.

No. 89. A colossal head of Antinous in the character of Bacchus; it is crowned with a wreath of ivy.

No. 90. A head of Diana, the hair of which is drawn up from the sides, and tied in a lnot at the top of the head. From the collection of Sir William Hamilton.

No. 91. A fragment of a bas-relief, representing three legs; they have belonged to two figures in powerful action, one of which appears to have been aiming 
aiming a blow at the other, who is falling. Be- ROOM $\mathrm{x}$. queathed by the late Charles Lambert, Esq.

No. 92. A head of Diana, somewhat similar to No. 90, but of superior work.

No. 93. A small domestic fountain, of a square form, which was used for sacred purposes.

No. 94. A bust of Minerva; the head only is antique. The helmet and the bust, which are of bronze, are, with some variations, copied from an ancient bust of Minerva which was formerly in the Vatican, but is now at Paris.

No. 95. An upright narrow piece of marble, ornamented with branches of the olive and the pine.

No. 96. A statue of an intoxicated Faun.

No. 97. A statue of Mercury, sleeping upon a rock.

\section{ELEVENTH ROOM.}

\section{MEDALS AND COINS.}

This collection, the basis of which was formed RooM XI. by the cabinets of Sir Hans Sloane and Sir Robert Antrqutres. Cotton, has been from time to time enlarged by many valuable purchases and donations, but principally by the munificent bequest of the Rev. C. M. Cracherode. It is comprehended under the three following heads :

1. Ancient Coins. 
ROOM XI. Antiquities.

2. Modern Coins.

3. Medals.

The first of these heads consists of Greek and Roman coins.

The Greek coins are arranged in geographical order, and include all those which are struck with Greek characters, in Greece or elsewhere, by kings, states or cities, which were independent of the Romans. With this class are placed likewise the coins of free states and cities, which made use of either the Etruscan, Roman, Punic, Spanish, or other characters.

The Roman coins are placed, as far as it can be ascertained, in chronological order. They consist of the $A s$ and its divisions: Family or Consular coins; Imperial coins struck in Rome; Imperial coins struck in Egypt; Imperial coins struck with Greek characters, in different states and cities which were subject to the Romans; Imperial coins struck in the Poman colonies; Imperial coins struck with Punic characters; Contorniates.

The second head, comprising modern coins, consists of Anglo-Saxon, English, Anglo-Gallic, Scotch, and Irish coins, and likewise the coins of foreign nations. This class is arranged according to the respective countries to which the coins belong, those of each country being lept separate.

The third head, which comprises a class considerably more modern than either of those which 
precede it, consists of medals struck in our own Room Xr. country, and of those which have been struck Astiqurties. abroad. These are arranged in the same manner as the modern coins.

\section{ANTE-ROOM.}

No. 1. In the centre of the Ante-room, at the ante-room. head of the stairs, is placed the celebrated Barberini Axtreviriss. vase, which was for more than two centuries the principal ornament of the Barberini Palace. This vase was purchased of Sir William Hamilton, nearly thirty years ago, by the Duchess of Portland, since which period it has been more generally known by the name of the Portland Vase. It was found about the middle of the sixteenth century, two miles and a half from Rome, in the road leading to Frascati. At the time of its discovery, the vase was inclosed in a marble sarcophagus, within a sepulchral chamber, under the mount called Monte del Grano. The material of which the vase is formed is glass; the figures, which are executed in relief, are of a beautiful opaque white; and the ground, which is in perfect harmony with the figures, is of a dark transparent blue. 'The subject of these figures is extremely obscure, and has not hitherto received a satisfactory elucidation; but the design and the sculpture are both truly admirable.

PART II.

E

This 
Axre-Room This superb: specimen of Greek art was deposited Axtourres. in the British Museum, in 1810, by His Grace the Duke of Portland.

No. 2. An ancient painting in fresco, representing deer; it was found in a subterraneous chamber at Scrofano, about sixteen miles from Rome. From the collection of Sir. William Hamilton.

No. 3. A bas-relief, in stucco, representing a winged boy, or genius, carrying a pedum across his right shoulder. From the collection of Sir ISillian. Hamilton.

No. 4. An ancient painting in fresco, representing a female figure holding a patera, on which a vase is placed. Presented, in 1771, by the Earl of Exeter.

No. 5. An ancient painting in fresco, representing two females seated, in the Arabesque style, on the curling branches of a plant; one of them is holding a vase, the other a tambourin. Between these figures is a bas-relief, in stucco, representing a human head surrounded with ivy, and underneath are two birds drinking out of a well. Piesented by Thomas Hollis, Esq.

\section{TWELFTH ROOM.}

\section{COLLECTION OF SIR WILLIAM HAMILTON.}

room xir. (Cases 1, 2, 3,4.) Penates, or household gods, Axtrquíries, in bronze. In the lower part of these cases are contained 
contained some large bronze vessels, one of which, room xir. in the form of a round deep patera, is remarkable for the beauty of its handles, which are raised above the edge: they represent two serpents holding an egg in their mouths; underneath the serpents is the æois of Minerva.

(Case 5.) A raven, the size of life, and seven large candelabra, in bronze. The raven was presented, in 1777, by Lord Seaforth. It is of the finest workmanship, and has probably accompanied a statue of Apollo.

(Case 6.) Specimens of ancient glass. The principal articles are eight cinerary urns. One of them has the leaden covering in which it was preserved; and another contains the burnt bones, and the asbestos cloth which prevented the ashes of the body from mixing with those of the funeral pile. These articles are accompanied by a great number of latz chrymatories, and various other vessels and frag ments of vessels, of different forms and colours, the whole of which afford ample proof of the ingenuity of the Ancients, and of the great knowledge they possessed in the art of manufacturing glass, and of imparting to it whatever colour or form they chose.

(Case. 7.) A large collection of pateræ, upon which are engravings, principally in outline. In this case are also exhibited the umbo of a shield and the scabbard of a parazonium, both of which are ornamented in like manner with engraved E 2 figures. 
Room xir. figures. The same case likewise contains two Anтquтris. bronze arms, executed in a good style; the largest appears to be of very early work.

(Case 11.) Necklaces, ear-rings, arnillæ, and various other trinkets in gold, several of which are enriched with precious stones. Among the antiquities of gold in this case is a bulla, and a large patera; the latter is embossed with bulls, and was found at Gergenti in Sicily. This case contains also a large collection of scarabæi and engraved gems, from the collections of Sir William Hamilton, Charles Towneley, Esq. and the Rer. C. 峦i. Cracherode. A piece of small mosaic work, and a few specimens of ancient art executed in silver, are likewise among the articles included in this case.

(Case 15.) Fiagments in terracotta. They consist chiefly of small heads, some of which are well execited, and some are valuable as exhibiting specimens of the Roman head-dresses.

(Case 16.) Small figures, and miscellaneous articles in terracotta.

(Case 17.) Hindu, Chinese, and Japanese idols. (Case 26.) Ditto.

(Case 27.) Small figures, and miscellaneous articles in terracotta.

(Cases 28, 32, 36.) Fragments of friezes in terracotta.

(Case 37.) Specimens of ancient armour in bronze, 
bronze, consisting of helmets, breast-plates, stand- Rooi Xm: ards, swords, belts, heads of spears, points of ar- Axreursizs. rows, \&c. In the middle division of this case is the Roman helmet which was found at Ribchester in Lancashire.

(Case 38.) A tripod, a lectisternium, a pair of steelyards, and two very large candelabra, in bronze.

(Cases 39, 40, 41, 42.) Miscellaneous antiquities in bronze, comprising scales, knives, pateræ, and simpula; mirrors, lamps, bells, and mortars; measures and wine-strainers; large vessels for culinary and other purposes; several small candelabra, and other articles.

(Cases 43, 44, 45.) A large collection of Roman lamps in terracotta.

(Cases 46, 47, 48.) Ditto.

(Cases 49, 50, 51.) Ditto.

(Case 52.) Dice and tali, formed of various substances.

(Casc 53.) A great variety of tesseræe in ivory, bronze, crystal, agate, and terracotta, many of which were tickets of admission to the theatres. In this case also is a considerable number of styles for writing on wax tablets; pins for the hair; bodkins, and needles both for sewing and netting.

(Case 54.) Architectural mouldings in porphyry, part of a frieze in rosso antico; handles of knives, fragments of lectisternia, \&c. \&c. 
ROOM XII. (Case 55.) Stamps for sealing casks.

Aatrquities. (Case 56.) A large collection of Roman weights. (Case 57.) Votive offerings in bronze.

(Case 58.) A brick taken out of the ruins of a large city, supposed to have been Babylon, near the town of Hillah, on the river Euphrates; it has an inscription in unknown characters.

(Case 59.) Specimens of ancient painting from Herculaneum.

(Case 60.) A brick similar to the one in Case 58.

(Cases $61,62,63$.$) Specimens of bas-reliefs in$ stucco, from the walls of Herculaneum.

Case 64.) Celts.

(Case 65.) Various instruments used by the Ancients.

(Case 66.) Celts.

(Case 67.) A marble patera, fourteen inches in diameter, found in the ruins of Hadrian's Villa: in this case are also contained specimens of Roman enamel, and inlaid work; and likewise some figs and other vegetable substances which were found in a calcined state in the ruins of Herculaneum.

(Case 68.) Armillæ or bracelets, and various unknown ornaments in bronze.

(Case 69.) A large patera of Oriental jasper, cups of crystal, agate, \&c.

(Case 70.) Hinges and nails.

(Case 71.) Fibulæ, or broaches. 
(Ctse 72.) Buckles used by the Ancients for dif-room xtr. ferent purposes.

(Case 73.) Handles and other parts of vases. AnTiqứties.

(Case 74.) Ditto.

(Case 75.) Specimens of locks and keys.

(Case 76.) Spears, knives, and various instruments in iron.

(Case 77.) Bits, spurs, and ornaments for harness; fragments of chains, \&c.

(Case 78.) Some articles in bronze; the use to which they were applied is unknown.

The intermediate and subsequent cases in this room are filled with Greek vases, of which great numbers were found in sepulchres within those parts of the kingdom of Naples, anciently called Magna Græcia. Most of these vases are ornamented with paintings, representing a variety of subjects, chiefly mythological, the compositions of which are truly elegant. The forms of the vases are much varied, and are equally simple and beautiful.

\section{THIRTEENTH ROOM.}

\section{PRINTS AND DRAWINGS.}

This Room contains an extensive and valuable Room xiIr. collection of prints and drawings, the most impor- Axtrqurres. tant part of which was bequeathed by the Rev. C. M. Cracherode.The contents of this Room, as 
ROom XiII. well as the collection of coins and medals, can be Axtrqutres. seen only by a few persons at a time, and by particular permission.

\section{FOURTEENTH ROOM.}

Room xiv. No. 1-23. Bas-reliefs, representing the battle Antrqutries. tween the Greeks and Amazons; they were found in the ruins of the temple of Apollo Epicurius, (or the deliverer) built on mount Cotylion, at a little distance from the ancient city of Phigalia in Arcadia. These bas-reliefs composed the frieze in the interior of the Cella. The battle of the Centaurs and Lapithæ is sculptured on eleven slabs of marble. (1-11.) That of the Greeks and Amazons occupies twelve. (12-23.) The direction of the slabs belonging to the former subject was from right to left; that of the latter from left to right: and it was probably the intention of the sculptor, by this contrivance, that the commencement of each contest should meet the eye of the spectator at one point of view on his entrance into the temple, and that the terminations of both combats should be presented to him in like manner, on his departure from the temple.

A circumstance which adds very much to the interest of these marbles, is our knowledge of the precise time when they were executed; for Pausanias, 
nias, in his description of this temple, informs us ROOM XIV. that it was built by Ictinus, an architect who was AnтrQurres. contemporary with Pericles, and who built the Parthenon at Athens.

No. 24. A fragment of a Doric capital of one of the columns of the Peristyle. From the same temple.

No. 25. A fragment of an Ionic capital of one of the columns of the Cella. From the same temple.

Nos. 26, 27. Two fragments of the tiles which surmounted the pediments, and formed the superior moulding. From the same temple.

No. 28-38. Fragments of the Metopes found in the porticos of the Pronaos, and Posticum, which were enriched with triglyphs. From the same temple.

No. 39. A small tile, which was used for the purpose of covering the joints of the greater tiles; the ornament in front surmounted the cornice. From the same temple.

No. 40. Another tile used for the same purpose, but on the point of the ridge. From the same temple.

The following articles contained in tlis Room form a part of the Coliection which belonged to the Earl of Elgin.

No. 41. An Egyptian scarabæus, or beetle, brought from Constantinople.

No. 42. An architectural statue; it was one of the Caryatides which supported the roof under which 
ROQMXIV. Which the olive tree of Minerva was sheltered, in ANTIQUTITIS. the temple of Pandrosus, at Athens.

No. 43. A piece of the shaft of an Ionic column.

No. 44. The capital of an Ionic column belonging to the temple of Diana, at Daphne, on the road from Athens to Eleusis.

No. 45. A piece of the shaft of an Tonic column, belonging to the sane temple.

No. 46. The base of an Ionic colnmn, likewise belonging to the same temple.

No. 47. The capital of an Ionic column, from the portico of the Erectheun at Athens. The building to which this singularly beautiful piece of architecture belonged, was a dotible temple dedicated to Minerva Polias and Pandrosus.

Nos. $48,49 . A$ portion of the shaft, and the base, of the same column.

No. 50. A solid monumental urn, or cenotaph, with a bas-relief in front not inscribed.

No. 51. Another monumental urn, of the same kind, inscribed with the name of Phædimus of Naucratis.

No. 52-54. Casts in plaster of three of the metopes of the north side of the temple of Theseus, at Athens. The first represents Theseus killing Creon, king of Thebes; the second, Theseus overcoming Cercyon, king of Eleusis, in a wrestling match and the third, Theseus killing the Crommian sow. 
No. 55-68. Casts in plaster from the frieze of roomxiv. the Pronaos of the temple of Theseus. The sub- ANтrutrus. ject of this frieze is a battle fought in the presence of six divinities, who are represented sitting in the midst of the combatants.

No. 69-73. Casts in plaster from the frieze of the Posticus of the same temple. 'The subject of these sculptures is the battle of the Centaurs and Lapithæ.

No. 74-88. Casts in plaster of the whole of the frieze at the west end of the Parthenon; these casts are arranged in the order in which the original marbles were placed in the temple.

No. 89-97. Casts in plaster of the frieze of the Choragic monument of Lysicrates, commonly called the Lantern of Demosthenes. The subject of this frieze is the story of Bacchus and the Tyrrhenian pirates.

Nos. 98, 99. Casts, in plaster, from one of the ends of the celebrated sarcophagus in the cathedral church at Agrigentum, which represents the story of Phædra and Hippolytus. Phædra is here represented surrounded by her female domestics, and plunged into grief at the refusal of Hippolytus, which has just been communicated to her. The attendants are endeavouring in various ways to console their mistress, and some of them attempt to alleviate her distress by the sounds of their instruments.

FIFTEENTH 


\section{FIFTEENTH ROOM.}

All the articles contained in this Room belonged to the Earl of Elgin.

rоом xv. No. 1-15. Fifteen of the metopes belonging Axtrutizs. to the Parthenon, which, alternately with the triglyphs, ornamented the frieze of the entablature surmounting the colomnade: they represent the battle between the Centaurs and Lapithæ, or rather between the Centaurs and Athenians, who under Theseus joined the Lapithre (a people of Thessaly) in this contest. In some of these sculptures the Centaurs are victorious, in others the Athenians have the advantage, while in others again the victory seems doubtful with respect to either of the combatants. These magnificent specimens of ancient art are executed with great spirit, in altorelievo; they were seen at a height of nearly fortyfour feet from the ground.

No. 16. A plaster cast of the metope, No. 7 .

No. 15\%-62. The exterior frieze of the Cella of the Parthenon, which embellished the upper part of the walls, within the colonnade, at the height of the frieze of the Pronaos, and which was continued in an uninterrupted series of sculpture entirely round the temple. It is in very low relief. The subject represents the sacred procession which 
took place at the great Panathenæa, a festival which room xv. was celebrated every fifth year, at Athens, in honour $\Lambda$ strqutras. of Minerva, the patroness of the city. The basreliefs which compose this frieze are arranged as nearly as it could be ascertained, and was compatible with the construction of the present room, in the same order as they were originally placed in the Parthenon. Those on the principal front of the temple, namely the east, are placed first, then follow those of the north, and lastly those of the west and south: they are arranged, in short, in the same manner in which they would be seen by the spectator who approached the temple by the east, and walked round it by the north, west, and south.

No. 15*-21. That portion of the above-mentioned frieze which occupied the east end of the temple. On two of the slabs which compose this part of the frieze are represented divinities and deified heroes, seated; namely, Castor and Pollux, Ceres and Triptolemus, Jupiter and Juno, and Aesculapius and Hygeia. There was originally a third slab, which represented four other divinities also seated, but it has disappeared for many years. On the right and left of these sacred characters, are trains of females with their faces directed to the gods, to whom they are carrying gifts; we see also directors or regulators of the procession, amongwhom are the officers whose duty it was to receive the presents that were offered. These females ap- 
Room xy. pear to have headed the procession, and to have ANTRUTrirs, been followed by the victims, charioteers, horsemen, \&c., both on the north and south sides of the temple, which together formed, a procession up to the same point in two separate columns.

No. 22-33. A portion of the same frieze, taken from the north side of the temple. No. 22 is a fragment of a much larger slab; it represents two of the Metoci, or strangers, that settled at Athens, and who were allowed to take part in the procession. They carry on their shoulders a kind of tray filled with cakes and other articles. The remainder of this part of the frieze represents charioteers and horsemen. Among the latter are seven slabs which. succeed each other in their original order, and which, whether we consider the elegance of the compositions, or the spirit with which the figures of the men and horses are executed, present us with the highest effort of the art of sculpture in the class of low relief.

No. 34-38. Seven slabs of the frieze from the north side of the temple; they ought to have been introduced, if the room would have permitted it, between Nos. 24 and 25. Three of these slabs represent charioteers, and two of them horsemen.

No. 38*. A single slab of the north frieze, which serves to fill up a chasm between Nos. 31 and 32 , and to complete the series from No. 25 to 33 inclusive.

Nos. 
Nos. 38**, 38***. Two slabs of the south frieze, room xv.

No. 39. A single slab of the frieze from the west Antraurirs. end of the temple. It represents two horsemen, one of whom is riding before the other, and seems to be in the act of urging his companion to quicken his pace. The direction of these figures is the same as that on the north side namely from right to left. There is a peculiarity in the frieze of the west end, which distinguishes it from that on the north and south sides of the temple. The subjects represented on the slabs of those two sides run one into another, that is, what was left imperfect in one slab is completed in the next; whereas in the west end the subjects are nearly complete on each piece of marble. The western frieze is likewise distinguished from those of the two sides, by the comparatively few figures which are introduced into it.

The frieze at the west end of the temple originally consisted of nfteen slabs, of which there is a perfect set of plaster casts preseryed in this collection. See Room XIV. (No.74-88.)

No. 40-62. A portion of the same frieze, namely, that portion which enriched the south side of the temple. It represents a procession of victims, charioteers, and horsemen, and is very sirilar in its general character and appearance to the frieze on the opposite or north side. With respect to the victims, we do not possess any that were on the north side of the temple; but that they formed a part of the 
RDOM XV. the procession on that side, as well as on the south, Anrrqutries. cannot be doubted, sirce Stuart, in his celebrated work on Athens, has engraved a fragment of one of them.

No. 63. A group of two of the Fates, from the east pediment of the Parthenon, on which was represented the birth of Minerva. Another figure in this collection (No.67) is supposed to have been one of the Fates, and to have formed a part of the same group.

No. 64. The upper part of the torso of Neptune, one of the principal figures in the west pediment of the Partheron. The subject of the sculptures represented on this pediment, was the contest between Minerva and Neptune for the honour of givingname to the city of Athens.

No. 65. The upper part of the figure of Hyperion rising out of the sea. His arms are stretched forward, in the act of holding the reins of his coursers. This figure, which represents the approach of day, is from the east pediment of the Parthenon, where it occupied the angle on the left of the spectator.

No. 66. The heads of two of the horses belonging to the car of Hyperion. They are just emerging from the waves, and seem impatient to run their course. From the east pediment oi the Parthenon.

No. 67. A female figure in a sitting posture, also from 
from the east pediment of the Parthenon. This is room XV. supposed to be one of the sister Fates, and to have Antrourtres. formed part of the group already described under No. 63.

No. 68. The head of one of the horses belonging to the chariot of Night, which was represented plunging into the ocean on the right angle of the east pediment of the Parthenon, that is to say, the right angle in reference to the spectator. The car of Day has been already described, as it was represented rising out of the waters on the opposite angle of the same pediment, (Nos. 65, 66.)

No. 69. The torso of Victoria Apteros, or Victory without wings, who was represented in this manner by the Athenians, to intimate that they held her gifts in perpetuity, and that she could not desert them. This goddess was represented driving the car of Minerva, on the west pediment of the Parthenon; the car approached Minerva, as if to receive her into it, after her successful contest with Neptrme.

No. 70. A recumbent statue, supposed to be of the river-god Ilissus. The Ilissus was a small stream that ran along the south side of the plain of Athens. This figure, which, with the exception of the Theseus, is the finest in the collection, occupied the left angle of the west pediment of the Parthenon.

No. 71. A statue of Theseus, the Athenian hero; he is represented half-reclined on a rock, which is covered with the skin of a lion. Theseus, it is well PART II. known, 
room xv. known, professedly imitated the character of Her. Axtrqutres. here given to Theseus is very similar to that of Hercules on some of the coins of Crotona. This wonderfully fine statue originally occupied a place in the east pediment of the Parthenon, next to the horses of Hyperion.

No. 72. A torso of Victory, from the east pediment of the Parthenon. The wings of this figure were probably of bronze; the holes in which they were fastened to the marble may still be seen.

No. 73. A fragment of a group which originally consisted of Latona with her two children, Apollo and Diana. This group was placed on the right side of the west pediment of the Parthenon. All that remains in the fragment before us, is the lap of Latona, with a small portion of the figure of the infant Apollo.

No. 74. A statue of Iris, one of the daughters of Oceanus, and the messenger of the celestial deities, particularly of Juno. It is from the east pediment of the Parthenon. Iris is represented in quick motion, with her veil inflated and fluttering behind her; and she appears evidently in haste to execute the mission on which she is sent, that of communicating to the distant regions of the earth the important intelligence of the birth of Minerva.

No. 75. A fragment of the statue of Minerva, one of the principal figures in the west pediment of 
the Parthenon, and of nearly the same proportions room XV. as the torso of Neptune, from the same pediment Anriqurtis. (No. 64). This fragment consists of a portion only of the chest of the goddess, which is covered, as usual, with the rgis. The angles of the æois appear to have been ornamented with bronze serpents, and the centre of it to have been studded with a head of Medusa, of the same metal; the holes in which these ornaments were fastened to the marble are plainly visible. The upper part of the head of this statue is still preserved in the collection. (See No. 118.)

No. 76. The torso of a male figure, supposed to be that of Cecrops, the founder of Athens. It is from the west pediment of the Parthenon.

No. 77. A group of two goddesses, probably intended to represent Ceres and her daughter Proserpine ; the latter is leaning on the right shoulder of her mother. They are sitting on low seats, which are perfectly alike in their construction, both of them being furnished with cushions, and ornamented with mouldings of a similar style. This group was in the east pediment of the Parthenon.

No. 78. A small figure of Telesphorus, completely enveloped in a cloak; it wants the head.

No. 79. The chest of a female figure, covered with drapery; it has probably belonged to one of the metopes of the Parthenon.

No. 80. The capital of an Ionic column, from the temple of Diana, at Daphne. 
Room xv. No. 81. A fragment of a boy, holding a bird Aлтr

No. 82. A bas-relief, representing a young man standing between two goddesses, Vesta and Minerva, who are crowning him.

No. 83. A Greek inscription in the Doric dialect; it is a dedication to Bacchus, by Alexas the son of Nicon, and Cephisodorus the son of Aglaophædas, who had both been victorious in the choruses of men.

No. 84. A fragment of a bas-relief, representing an elderly man before one of the gods, probably Bacchus, who appears to hold a vase in his right hand.

No. 85. A piece of the architrave of the Erectheum, at Athens.

No. S6. A votive Greek inscription of Antisthenes, the priest of Pandion: he was the son of Antiphates, and belonged to the tribe of Pandionis.

No. 88. A Greek inscription from Athens, signifying that certain gifts, which are specified, had been consecrated to some goddess, probably Venus, by a female who held the office of lighter of the lamps, and interpreter of dreams, in the temple of the goddess. The name of this female, which was no doubt inserted at the beginning of the inscription, is now lost.

No. 89. A fragment of a bas-relief, representing Minerva placing a crown upon a person's head.

No. 90. 
No. 90. A small female figure, covered with Room Xv. drapery; it is without a head.

No. 91. A circular votive altar, ornamented with the heads of bulls, from which festoons are suspended. The inscription, in Greek, near the bottom, is a prayer for the prosperity and health of a person named Casiniax.

No. 92. A Greek inscription, written in two columns; it contains a list of names arranged in the order of the tribes to which they respectively belonged.

No. 93. An agonistic inscription, in Greek, consisting of the names of those who had conquered in the foot race of the stadium, and double stadium; in wrestling; in boxing; in the pancratiun; and pentathlum.

No. 94. A bas-relief, imperfect, representing a goddess seated on a chair or throne, behind whom are seven figures, four of which are children; one of the latter is leading a ram to an altar, the rest are in the attitude of devotion.

No. 95. A fragment of the upper part of a sepulchral stêle.

No. 96. A fragment of a bas-relief; belonging to the frieze of the Parthenon.

No. 97. A bas-relief, representing a votive figure of Cybele, seated in a kind of small temple.

No. 98. A fragment of a bas-relief, belonging 
Room xv. to the frieze on the north side of the Parthenon; Antroutities. it is a part of the slab, No. 35.

No. 99. An oblong shallow vessel for containing holy water. The front is ornamented with a bas-relief representing five figures, one of which, probably Juno, is seated on a throne: of the remaining figures, three fernales are imploring the benediction of the goddess in behalf of their children, whom they are carrying in their arms, and a fourth is bringing oblations. From Cape Sigeum, near the plain of Troy.

No. 100. An unknown bust.

No. 101. A fragment of a bas-relief, representing three figures sacrificing before an altar.

No. 102. A fragment of the capital of a Corinthian column; it is ornamented with the leaves of the laurel and acanthus.

No. 103. A fragment of a bas-relief, representing two of the goddesses, Latona and Diana, in procession. Similar bas-reliefs, in a more perfect state, are preserved in the Albani collection. The temple which is here introduced is probably that of Apollo, which stood in the street at Athens, called " the tripods."

No. 104. A fragment of a cinerary urn, on which are represented four figures in bas-relief. The two central figures consist of a young man and woman, who are joining hands, and whose names are inscribed 
scribed above in Greek characters, Demostrata and room xv. Callistus. Two other figures are standing by the Antrourtres. side of these, in a pensive attitude.

No. 105. The upper part of the head of an Egyptian idol, in granite; the head is that of a lion, and is remarkable for being ornamented with a crown of serpents, similar to that which is spoken of in the Rosetta inscription.

No. 106. A circular altar, from the island of Delos; it is ornamented with the heads of bulls and festoons in very bold relief.

No. 107. A fragment of a bas-relief, representing a figure standing upright in a dignified attitude; it is probably intended for Bacchus.

No. 108. A bas-relief, imperfect; it represents three goddesses, one of whom is seated on a throne.

No. 109. A fragment of a bas-relief, representing part of the body and legs of a boy.

No. 110. A solid urn, or cenotaph, in the front of which two figures, a man and woman, are represented joining hands. The former is standing, the latter is seated. The names of both were probably inscribed upon the urn, but that of the woman only is preserved, Ada.

No. 1II. A sepulchral column of Mysta: the Greek inscription informs us that she was a native of Miletus, daughter of Dionysius, and wife of

Rhaton, 
Room xv. Rhaton, who was a native of Thria, a town belongAntrourtes, ing to the tribe of Oeneis.

No. 112. A fragment of a square-altar, which has probably been dedicated to Bacchus. The ornaments on two of the sides only have been preserved; these represent female Bacchantes in dancing attitudes. One of the figures holds a shawl or veil in her hands, the other brandishes a thyrsus.

No. 113. A small tile, in terracotta, which has been used to cover the joints of the larger tiles. The front is enriched with a fieuron, and is also inscribed with the name of the maker, Athenæus.

No. 114. An unknown female head, the hair of which is confined within a close elegantly formed cap. The same style of head-dress is observable on some of the silver coins of Corinth.

No. 115. The head of a laughing figure, executed in the early hard style of Greek sculpture.

No. 116. The head of a middle-aged man, with a conical bonnet; it appears to have had very little beard, and is most probably the head of a mariner.

No. 117. A head of the bearded Hercules.

No. 118. The upper part of the head of Minerva: the statue to which it belonged, formed one of the principal figures in the west pediment of the Parthenon. This head was originally covered with a bronze helmet, as appears from the holes by which 
which it was fastened to the marble; and the room xv. sockets of the eyes, which were originally filled with $\Lambda$ NTiquitis. metal or coloured stones, are now hollow. This fragment of a head, and the portion of a female chest, already described (No. 75.), have both belonged to the same statue of Minerva.

No. 119. An unknown bearded head, very much mutilated; it is larger than life, and is crowned with a very thick cord-shaped diadem.

No. 120. A head of the bearded Hercules, similar to No. 117, but of smaller dimensions.

No. 121. A fragment of a head, crowned with vine leaves; it appears to have been executed at a declining period of the arts.

No. 122. An unknown female head, the hair of which is concealed within a close head-dress.

No. 123. A fragment of a bas-relief, representing an unknown female head; from the style of the hair, which is curiously plaited, we may fix the sculpture to about the time of Antoninus Pius.

No. 124. Part of the stem of a candelabrum ornamented with four female figures, one of which is playing on the lyre, and the others, with joined hands, are leading the dance.

No. 125. A fragment of a statue of Hygeia.

No. 127-130. Four pieces of the frieze from the temple of Erectheus at Athens; they are enriched with flowers and other ornanents, which are designed with the most perfect taste, and are chiseled 
Room XV chiseled with a degree of sharpness and precision Axtrutries.

No. 134-147. Fragments of figures, many of which have belonged to the metopes of the Parthenon.

No. 148. A cinerary urn, ornamented in front with four standing figures; two of these, in the centre, are joining hands, the other two are in a pensive attitude. The names of all the figures were originally inscribed on the urn ; the first name is not legible; the others are Philia, Metrodora, and Meles.

No. 149. A sepulchral column of Thalia, the daughter of Callistratus, of Aexone.

No. 150. A fragment of a sepulchral stêle; the inscription is very imperfect, but records the name of Musonia. The summit is ornamented with the figure of a butterfly on some fruit.

No. 151. A fragment of a statue covered with drapery.

No. 152. A sepulchral Greek inscription, in ten verses, of which the two first and the two last are in the elegiac measure, and the rest are hexameters. The inscription is in memory of a young lady of extraordinary beauty, named Tryphera, who died at the early age of $\mathbf{2 5}$ years.

No. 153. A sepulchral Greek inscription, engraved on a piece of entablature. It consists of two lines in prose, and sixteen in pentameter verse.

The 
The name of the deceased was Publius Phædrus, Room xv. a native of Sunium, the son of Theophilus and Ce- Axrmqutres. cropia, and grandson of Pistoteles. The inscription states that he was of noble family, and that his death was followed by the universal regret of the Athenians, on account of his youth, learning, wisdom, and personal accomplishments.

No. 154. A piece of Doric entablature, originally painted.

No. 155. The upper part of a sepulchral stêle, inscribed with the name of Euphrosynus.

No. 156. A fragment of a colossal female statue, from one of the pediments of the Parthenon; it has belonged to a sitting figure, of which the only remaining part is the left thigh, covered with drapery.

No. 157. A fragment of a decree; the beginning is wanting, and what remains is much mutilated. At the conclusion of the decree, it is ordained that the people of Hierapytna in Crete shall affix to it the public seal.

No. 158. A fragment of a bas-relief, on which are represented part of the skin of an animal and the branch of a tree.

No. 159. A fragment of a very ancient Greek inscription from the Acropolis; it contains an account of certain expenses defrayed by those to whom the care of the public games was confided. The name of the Archon under whom the stone was engraved is effaced.

No. 160. 
Room xv. No. 160. A fragment of a bas-relief, representing Astravities, the fore legs and part of the body of a bull.

No. 161. A fragment of a decree made by a society which is distinguished by a number of epithets, among which are two derived from the names of Hadrian and Antoninus. The society appears to have been formed of musicians, and the decree to have been passed in honour of Bacchus and the Emperor Antoninus Pius. A patera is represented on the upper part of this marble.

No. 162. A fragment of a bas-relief, representing a female figure seated in a chair, with a child standing by her side; the upper part of the woman is wanting. This fragment is probably part of a sepulchial monument.

No. 163. A sepulchral solid urn, ornamented with reeds, and inscribed with the name of Timophon, the son of Timostratus, and a native of Anagyrus, whose inhabitants were of the tribe of Erectheis.

No. 164. A sepulchral column inscribed with the name of Socrates, son of Socrates, and a native of Ancyra, a city of Galatia.

No. 165. A portion of the cornice from the portico of the Erectheum, at Athens.

No. 166. A fragment of a bas-relief, of large dimensions; it represents Hercules preparing to strilie Diomed, king of Thrace, whom he has alreacy Inocked down, and is holding by the hair of his head.

No. 167. 
No. 167. A sepulchral solid urn, having three Room Xv. figures in bas-relief on the front. 'The first of Aмriqutres. these is a warrior with a helmet and shield, who is joining hands with an elderly man, dressed in a long tunic; the third figure is a fernale. The inscription underneath these figures probably contained the names of the parties, but is too mutilated to admit of being decyphered.

No. 168. A sepulchral column of Menestratus, the son of Thoracides, and a native of Corinth.

No. 169. The upper part of a sepulchral stêle, having the inscription, as well as the arabesque ornament on the summit, perfect. The inscription is to the memory of Asclepiodorus the son of Thraco, and Epicydes the son of Asclepiodorus; both the deceased were natives of Olynthus, a city in Macedon.

No. 170. A fragment of a Greek inscription; it is too imperfect to admit of a full explanation, but it seems to have been in honour of a person who had distinguished himself on some occasion by great humanity.

No. 171. An amphora.

No. 172. A sepulchral stêle, with a Greek inscription, consisting of four lines and a half, part of which is written in prose and part in verse. The inscription informs us that the monument was erected by a mother to the memory of her two sons, Diitrephes and "Pericles, the former of whom 
roon xv. was a soldier of Parium; and also to the memory Axtrutrizs, of her daughter, whose name was Agnes, and that of her brother Demophoon, who was a soldier of Parium.

No. 173. A fleuron, from the temple of Ceres, at Eleusis.

No. 174. A capital of a pilaster.

No. 175. A sepulchral stêle, with an ornament of flowers on the summit. It is inscribed with the names of Hippocrates and Baucis.

No. 176. An amphora.

No. 177. A Greek inscription, imperfect, but of which fifty-five lines remain. It is written in the Bootian, Eolic dialect, and is a treaty between the cities of Orchomenus in Bøotia, and Elatæa in Phocis, respecting some payments due from the Orchomenians to the Elatæans. These payments were for the rent of certain pastures which the people of Elatra had let out to the Orchomenians. The treaty confirms the payment of the stipulated sums, and renews the treaty of pasturage for four years.

No.178-198. Twenty-one fragments of Greek inscriptions, so imperfect as scarcely to admit of particular descriptions.

No. 199. The celebrated Sigean inscription, first published by Chishull in his "Antiquitates Asiaticæ," and afterwards more correctly by Chandler in his "Inscriptiones Antiquæ." It is written in the 
most ancient Greek characters, and in the bustro- Room xv. phedon manner, that is to say, the lines follow each Anтriquiris. other in the same direction as the ox passes from one furrow to another in ploughing. The purport of the inscription is to record the presentation of three vessels, namely a cup, a saucer or stand, and a strainer, for the use of the Prytaneum, or hall of justice, of the Sigeans. The name of the donor was Phanodicus, the son of Hermocrates, and a native of Proconnesus.

No. 200. A Greek inscription, imperfect, engraved in very ancient characters; it seems to be an inventory of some treasures, probably those contained in the Parthenon, and which the Quæstors acknowledge to have received from their predecessors in the same office. The inscription not only fills one side of the marble, but also the right edge.

No. 201. The base on which a statue has stood; the feet, which still remain, are very wide apart, and show that the figure must have been in powerful action.

No. 202. A torso of a male figure, probably that of Aesculapius.

No. 203. A sepulchral column to the memory of Callis, who was the daughter of Strato, and a native of the city of Gargettus.

No. 204. A base of a column, brought from the plains of Troy. 
Room xv: No. 205. A colossal statue of Bacchus, from the ANTrquriss. choragic monument of Thrasyllus, at Athens. It is a sitting figure, covered with the skin of a lion, and with a broad belt round the waist; it was originally placed on the summit of the edifice, at a height rather exceeding twenty-seven feet.

No. 206. A capital of a Doric column, from the Propylæa, at Athens.

No 207. A piece of the shaft of one of the Doric columns of the Parthenon.

No. 208. A small statue of a Muse, without a head; it was probably intended to represent Polyhymnia.

No. 209. A sepulchral column, inscribed with the name of Callimachus, who was a native of the city of Aexone, and the son of Callistratus.

No. 210. A base of a column, brought from the plains of Troy.

No. 211. An amphora.

No. 212. A sepulchral stêle, with a bas-relief representing a man clothed in a tunic. The inscription over this figure records the name of Erasippus, who was the son of Callinicus, and a native of Oeum in Attica.

No. 213. A sepulchral stêle, in which an equestrian figure, with an attendant on foot, is represented in bas-relief. Above the figures is an inscription, consisting of three verses, of which the second is a pentameter, and the two others, hexameters ; 
meters; they record the name of the deceased, Room Xv. Aristocles, who was the son of Menon, and a native Axriquiries. of Piræus.

No. 214. A sepulchral stêle, with a very ancient inscription to the memory of Aristophosa and others. A peculiarity occurs in this inscription, namely, that the letters uo are twice used for vıov.

No. 215. An amphora.

No. 216. A Greek inscription, imperfect, containing an account of the treasures of some temple, probably those of the Parthenon. The characters which we see on this marble are of a much more modern form than in the inscription of the same kind (No. 200) which we have lately described.

No. 217. The upper part of a sepulchral column, with an inscription to the memory of a person named Simon, who was the son of Aristus, and a native of Halæ in Attica.

No. 218. A fragment of a sepulchral stêle, from which the bas-relief has been almost entirely broken away; the inscription is to the memory of Hieroclea, the daughter of Leucius.

No. 219. A votive monument with two Greek verses, signifying that Horarius had dedicated some lamps which he won in the games to Mercury and Hercules. The bas-relief above, which probably represented the two deities here mentioned, is almost entirely broken away; only the feet of one figure remain.

PART II. 
Room xV. No. 220. A piece of a frieze, or architectural Antratimas. ormament, from the tomb of Agamemnon, at $\mathrm{MY}$ cenæ. The sculpture is exceedingly ancient, and consists of two kinds of scroll work, one of which represents the curling of the waves, and the other a series of pateræ which are perfectly flat and plain. The stone is of a brilliant green colour

No. 221. Another piece of frieze, or architectural onament, from the same place as the last-mentioned article. It consists of three rows of scroll work, all of which are similar representations of the revolving of the waves. The colour of the stone is bright red.

No. 222. A fragment of a Greek inscription, containing a list of Athenians, with the townships to which they respectively belonged. IVe read the names of no less than twelve different townships in this small fragment; namely, according to the order in which they occur, Sunim, Ionidæ, Alopece, Pallene, Halæ, Ericea, Colonus, Sphettus, Ceriadæ, Thoricus, Hephæstia, and Bate.

No. 223. A votive Greek inscription, dedicated by some sailors, as a mark of their gratitude, to Apollo of Tarsus.

No. 224. Ditto, dedicated by Gorgias, the Gym. nasiarch.

No. 225. A sepulchral column with an inscription to the memory of Theodotus, who was the son of Diodorus, and a native of Antioch.

No. 226. 
No. 226. The upper part of a sepulchral stêle, room xv: ornamented with leaves and flowers; the inscrip- Aлтrqutris. tion is to the memory of Chabrias.

No. 227. A bas-relief, representing two divinities, namely, Jupiter seated on a throne, and Juno standing before him; the latter is removing the veil from her face, as if to address the king of the. gods.

No. 228. A very large funeral urn, solid, and withont any inscription. It has three figures in basrelief; the first of these is clothed in a tunic and is seated; the second is a warrior standing up and joining hands with the former; and the third is a boy carrying a large circular shield.

No. 229. A sepulchral stêle. The bas-relief in front, the lower part of which is broken away, represents two females joining hands, one of whom is seated and veiled, the other standing. Between these appears an old man, clothed in a tunic, and standing in a pensive attitude.

No. 230. A fragment of a Greek inscription; it is the latter part of a decree in honour of a person who had deserved well of some particular city. It is directed, that the decree shall be engraved on marble, and placed in the temple of Neptune and Amphitrite. It appears, from the inscription immediately following, that the city here alluded to, was that of the island of Tenos. Strabo and Tacitus mention a celebrated temple that was dedi-
G 2
cated 
Room XV. cated to Neptune in this island, and it is highly Antrqurims. probable that the same temple was dedicated to Amphitrite, as well as to Neptune. Neptune and his symbols frequently occur on the medals of Tenos.

No. 231. A decree of the people of Tenos, in honour of Ammonius, their benefactor; this decree, like the last, is directed to be engraved on marble, and affixed in the temple of Neptune and Amphitrite.

No. 232. A fragment of a decree of the people of 'T'enos, in honour of some benefactor, whose name is not preserved on the marble.

No. 233. A fragment of a public act of the Athenians; it consists of twenty-one imperfect lines, and seems to relate to the repair of the pavements and roads in the neighbourhood of Athens.

No. 234. A fragment of a public act relating to the people of Athens and Myrina.

No. 235. A bas-relief, representing a Bacchanalian group, found among the ruins of the theatre of Bacchus, on the south-west of the Acropolis. It consists of four figures, each carrying a thyrsus; one of these is Bacchus, dressed in the Indian costume, who with his right hand is holding out a double-handled rase, into which a female Bacchante is pouring wine from a monota, or vase with one handle. On each side of these figures is an elderly 
Faun in a dancing attitude, one of whom is glancing koom $\mathrm{xV}$. his eye at the contents of a large vessel of wine antrourtirs. placed on the ground.

No. 236. A bas-relief, imperfect, representing a charioteer driving four horses at full speed; a figure of Victory is flying towards him with a crown.

No. 237. A solid funeral urn, of large dimensions. It has a bas-relief in front, representing two figures joining hands; these figures consist of a female who is seated, and a man who is standing before her. The Greek inscription gives us the names of both persons: one is Pamphilus, the son of Mixiades, and a native of Aegilia; and the other is Archigge, the daughter of Mixiades.

No. 238. A bas-relief, representing Hygeia feeding a serpent out of a patera. She is seated on a throne which is covered with a cushion, and her feet are placed upon a footstool. She wears a high ornament, or tutulus, on her head, and she has a fan, in the shape of an ivy leaf, in her left hand.

No. 239. A solid sepulchral um, with a basrelief representing five figures, executed in a singularly rude style. The first of these figures is a boy carrying a large circular shield, the second is a warrior joining hands with a third person who is seated before him; the group is completed by the intro- 


\section{6}

ROOM XV. duction of a child, and of a female whose attitude A.triquitres. evinces a dejected state of mind. Over the warrior is the name of Sosippus, in Greek letters.

No. 240. A sepulchial column, inscribed with the name of Anaxicrates, an Athenian, the son of Dexiochus; beneath the inscription is the representation of a sepulchral urn, executed in very low relief.

No. 241. A Greek inseription; it is a prayer in behalf of Euphrosynus.

No. 242. A sepulchral inscription, in six elegiac verses, to a young man of the name of Plutarch, who died in Ausonia, at a distance from his native country.

No. 243. An architectural fragment, which has formed one of the ornaments of a roof.

No. 244. A part of a colossal foot, probably be. longing to a figure in one of the pediments of the Parthenon.

Nos. 245-251. Seven bas-reliefs, of small dimensions: they represent various parts of the body, and have been offered up as vows to Jupiter Hypsistos, as prayers for the cure of diseases in those parts. Some of these bas-reliefs àppear to have been presented by the parties in gratitude for cures already received.

No. 252. A fragment of a bas-relief, similar to those just described. The part of the body which had received a eure has been broken off, but 
but the inscription implies, that Syntrophus pre- Room xV. sents it as a mark of his gratitude to Jupiter Axtrutrese. Hypsistos.

No. 253. A fragment of a similar bas-relief; the inscription has been broken off, but the part represented is a foot.

No. 254. An architectural fragment, similar to No. 243.

No. 255. A fragment of an unknown female head:

No. 256. The left knee of a colossal statue of very fine work; it has probably belonged to a figure in one of the pediments of the Parthenon.

Nos. 257, 258. Two bas-reliefs, which formed part of the frieze of a temple of the Ionic order (near the Propylæa at Athens) and dedicated to Aglauros. The subject represented on them is a combat between the Greeks and Persians.

Nos. 259, 260. 'Two bas-reliefs from the same temple; the combatants appear to be all Greels.

Nos. 261-273. Wragments of colossal statues, some of which have probably belonged to figures which stood in the pediments of the Parthenon.

No. 274. A sepulchral solid um, with a basrelief representing three figures, one of which is seated. The inscription presents us with the following names: Archagoras, Pithyllis, and Polystratus.

$$
\text { No. } 275 .
$$




\section{8}

Rоом xv. No. 275. A sepulchral column, with an inscripAntrevities, tion to the memory of Biottus, who was the son of Philoxenus, and a native of Diradium.

No. 276. A bas-relief, representing a narrow upright vase with one handle; the form of this vase very much resembles that of the solid urns, so often used by the Greeks as sepulchral monuments.

No. 277. A Greek inscription, imperfect, and very much defaced. It seems to be an inventory of valuable articles contained in some temple.

No. 278. A sepulchral column, inscribed with the name of Botrichus, son of Euphanus and a native of Heraclea.

No. 279. A fragment of a bas-relief, representing a female sitting.

No. 280. A fragment of a Greek inscription; it is a decree of the people of Athens in honour of Hosacharas, a Macedonian. This decree was passed in the Archonship of Nicodorus, in the 3d year of the 116th Olympiad.

No. 281. A fragment of a decree of the Athenians engraved on a very large piece of marble. So much has been broken away from this inscription, that the precise object of it is not easily collected; it is ordained, however, that the decree shall be fixed up in the Acropolis.

No. 282. A fragment of a Greek inscription, engraved in very ancient characters. It seems to 
be a treaty between the Athenians and the people noom xv. of Rhegium, a town of the Bruttii, in Italy.

No. 283. A Greek inscription, imperfect, engraved in very small characters. It is an enumeration of the sacred dresses which belonged to some temple.

No. 284. A fragment of a bas-relief representing a procession of three figures, the last of which carries a large basket on his head; they are accompanied by two children.

No. 285. A sundial, with four different dials represented on as many faces. The inscription imports that it is the work of Phædrus the son of Zoilus, a native of Pæania. From the form of the letters of this inscription, the sundial cannot have been made much earlier than the time of the Emperor Severus. It was found at Athens.

No. 286. A fragment of a Greek inscription; it consists of twenty lines of very ancient characters, and seems to be a part of a treaty.

No. 287. A Greek inscription, imperfect.

No. 288. Ditto, relating to the Erythræans; the characters are very ancient.

No.290. A very ancient Greek inscription which has served as an epitaph on the tomb of the Athenian warriors killed at Potidæa. This inscription, which originally consisted of twelve elegiac verses, has suffered from the injuries of time.

No. 291. 
room xy. No. 291. A piece of the architrave, belonging to Axrournes. the temple of Erectheus, at Athens.

No. 292. A funeral inscription to the memory of Polyllus; it consists of one line in prose, and two in verse. The line in prose gives us only the name and titles of Polylus, and the verses intimate that Polystratus had erected a statue to the deceased, and had placed it under the protection of Minerva: the marble on which this inscription is cut, formed a part of the base on which the statue stood.

No. 293. A small statue of a boy, imperfect; he is in the attitude of looking up.

No. 294. A fragment of a metope of the Parthenon; it is the torso of one of the Lapithæ.

No. 295. The capital of an Ionic colum belonging to a temple of Diana, at Daphne, in the road to Eleusis.

No. 296. A female torso, covered with drapery.

No. 297. A piece of the shaft of a small Ionic column, the lower part of which is fiuted and reeded.

No. 298. A Greek inscription, engraved on two sides of a large piece of marble. It is an inventory of the sacred treasures belonging to the Parthenon.

No. 299. A piece of the cieling of the temple of Erectheus, at Athens.

No. $299 *$. The lower part of a female statue, covered with drapery.

No. 299**. Part of the capital of an Ionic column.

No. 300. 
No. 300. A bronze urn, very richly wrought. Room xv. It was found inclosed within the marble vase in Axtrqurses, which it now stands, in a tumukis on the road that leads from Port Piræus to the Salaminian ferry and Eleusis. At the time of its discovery, this beautiful urn contained a quantity of burnt bones, a lachrymatory of alabaster, and a wreath of myrtle in gold.

No. 301. A large marble vase; it is of an oval form, and within it was found the bronze urn described in the preceding number.

No. 302. A Greek inscription, engraved on two sides of a tablet of marble. It is a decree of the council of the Bootians, ordaining the election of three extraordinary magistrates, who, in concert with the ordinary magistrates, were to take charge of the recasting some articles of gold and silver, belonging to the temple of Amphiaraus, and which had been injured by the effects of time.

No. 303. A piece of the shaft of a column, belonging to the temple of Erectheus, at Athens.

No. 304. A piece of the shaft of a column, also belonging to the temple of Erectheus.

No. 305. A Greek inscription, engraved on two sides of a thick slab of marble. It is an inventory of the valuable articles which were kept in the Opisthodomos of the Parthenon, at Athens.

No. 305*. An imperfect statue of a youth; it is of the size of life, and of the most exquisite workmanship.

No. 306. 
roou xv. No. 306. A sepulchral column, of large dimenAnTlarress. sions; it is inscribed with the name of Aristides, who was the son of Lysimachus, and a native of Estiæa.

No. 306 *. Part of the capital of an Ionic column.

No. 307. A circular altar, brought from the island of Delos. It is ornamented with the heads of bulls, from which festoons of fruit and flowers are suspended.

No. 308. A part of a Doric entablature, from. the Propylæa, at Athens.

No. 309. A Greek inscription engraved on three sides of a piece of marble. The characters are extremely ancient; but unfortunately the marble has been very much mutilated, and the letters defaced.

No. 310. The upper part of the shaft of a small Ionic column.

No. 311. A Greek inscription, engraved on two surfaces of a tablet of marble. It is an inventory of articles of gold and silver belonging to the Parthenon, and which the quæstors of the temple acknowledge that they have received from their predecessors.

No. 312. A piece of the shaft of an Ionic column, belonging to the temple of Erectheus, at Athens.

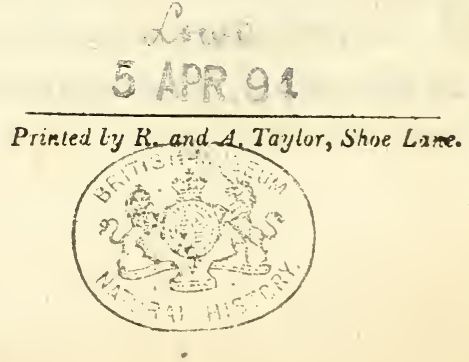







